\title{
Fibrinogen and Bleeding in Adult Cardiac Surgery: A Review of the Literature
}

\author{
Višnja Ikić ${ }^{1,2} \mathbb{D}$ \\ 1 Department of Anesthesiology, Resuscitation and Intensive Care, University Hospital Centre Osijek, \\ 31000 Osijek, Croatia; visnja.ikic@kbco.hr \\ 2 Faculty of Medicine, Josip Juraj Strossmayer University of Osijek, 31000 Osijek, Croatia
}

check for updates

Citation: Ikić, V. Fibrinogen and Bleeding in Adult Cardiac Surgery: A Review of the Literature. Surgeries 2021, 2, 409-436. https://doi.org/ 10.3390 /surgeries2040041

Academic Editor: Cornelis F. M. Sier

Received: 20 September 2021

Accepted: 22 November 2021

Published: 27 November 2021

Publisher's Note: MDPI stays neutral with regard to jurisdictional claims in published maps and institutional affiliations.

Copyright: (C) 2021 by the author. Licensee MDPI, Basel, Switzerland. This article is an open access article distributed under the terms and conditions of the Creative Commons Attribution (CC BY) license (https:// creativecommons.org/licenses/by/ $4.0 /)$.

\begin{abstract}
Background: Fibrinogen is a substrate for blood clots formation. In cardiac surgery, a number of different mechanisms lead to a decrease in fibrinogen levels and consequent impaired haemostasis. Patients undergoing cardiac surgery are therefore frequently exposed to blood loss and allogeneic blood transfusion, which are risk factors associated with morbidity and mortality. Thus, particular efforts in fibrinogen management should be made to decrease bleeding and the need for blood transfusion. Therefore, fibrinogen remains an active focus of investigations from basic science to clinical practice. This review aims to summarise the latest evidence regarding the role of fibrinogen and current practices in fibrinogen management in adult cardiac surgery. Methods: The PubMed database was systematically searched for literature investigating the role and disorders of fibrinogen in cardiac surgery and diagnostic and therapeutic procedures related to fibrinogen deficiency aimed at reducing blood loss and transfusion requirements. Clinical trials and reviews from the last 10 years were included. Results: In total, 146 articles were analysed. Conclusion: The early diagnosis and treatment of fibrinogen deficiency is crucial in maintaining haemostasis in bleeding patients. Further studies are needed to better understand the association between fibrinogen levels, bleeding, and fibrinogen supplementation and their impacts on patient outcomes in different clinical settings.
\end{abstract}

Keywords: fibrinogen; blood coagulation; haemostasis; blood transfusion; blood coagulation tests; cardiac surgical procedures

\section{Introduction}

Fibrinogen is a glycoprotein crucial in maintaining and restoring haemostasis. As the mediator of platelet aggregation and the substrate for fibrin formation, it is essential for effective clot formation.

Fibrinogen promotes platelet aggregation binding to glycoprotein GPIIb/IIIa receptors on platelets, leading to the formation of the primary platelet plug at the site of injury [1]. Fibrinogen is a precursor of fibrin, a key component of the clot that stabilises the initial platelet plug. Conversion of fibrinogen to fibrin is the final step of a sequence of enzymatic reactions in the coagulation process [1]. Fibrin polymerisation creates the insoluble fibrin network necessary for the formation of stable clots. Activated factor XIII additionally improves the clot strength by crosslinking the fibrin polymers. The clotting process is in balance with the fibrinolytic system that dissolves fibrin and prevents vascular obstruction and thrombosis.

Fibrinogen is an acute-phase protein. Its synthesis increases in response to surgical injury and cardiopulmonary bypass (CPB)-induced inflammatory response. In the absence of bleeding, fibrinogen levels rise after surgery, providing wound healing, angiogenesis, tissue regeneration, inflammation, and the prevention of infection [2].

Cardiac surgery and exposure to $\mathrm{CPB}$ result in a dilution, consumption, and loss of all coagulation factors, including fibrinogen [3-7]. Most coagulation factor levels are typically reduced by $30-50 \%$ after CPB [7-10]. Hypofibrinogenemia can occur in 50\% of patients during complex cardiac surgery [11]. This results in the formation of small 
and unstable clots and, consequently, impaired haemostasis [7,12]. Fibrinogen-dependent poor clot strength after cardiac surgery may be the major cause of postoperative bleeding $[13,14]$. Low platelet count or platelet dysfunction, low concentration of coagulation factors, hyperfibrinolysis, residual heparin effect, acidaemia, low calcium concentration, hypothermia, and surgical sources may cause bleeding, coagulopathy, and fibrinogen loss or may contribute to fibrinogen-related bleeding and lead to the further decrease of fibrinogen concentration and function [13,15].

Patients undergoing cardiac surgery have an increased risk of bleeding and allogeneic blood product transfusion [16]. According to the Universal Definition of Perioperative Bleeding (UDPB), 9.8\% of patients undergoing cardiac surgical procedures with CPB meet the criteria for severe and massive bleeding and $51.4 \%$ of patients for insignificant bleeding [17]. Using the UDPB, recent studies have shown even higher percentages of patients who had severe and massive bleeding (17.6-23.8\%) [18,19]. Between 30 and $60 \%$ of cardiac surgery patients are transfused with allogeneic blood products [20-22], and 2-6\% patients are reexplored due to bleeding or cardiac tamponade [23-27]. Major bleeding [28], blood product transfusion [22,26,28], and surgical re-exploration [23-27] are independently associated with increased morbidity and mortality.

To improve patient outcomes, particular efforts in perioperative fibrinogen management should be made to maintain haemostasis and minimise blood loss and the need for blood product transfusion.

This review aims to summarise the latest evidence related to the physiology of fibrinogen and its role in haemostasis, fibrinogen disorders, and the main factors leading to decreased fibrinogen levels and consequent bleeding in adult cardiac surgery, diagnostic procedures, and possible prophylactic and therapeutic interventions to optimise patient outcomes.

\section{Materials and Methods}

A systematic search of the electronic PubMed database was performed using the following keywords: fibrinogen and cardiac surgery. Research filters were applied restricting searches to humans, adults (over 18 years), and English language publications. All articles from 1 January 2011 to 1 July 2021 were considered.

Original articles and reviews discussing the physiology of fibrinogen; the role of fibrinogen; and fibrinogen disorders in adult cardiac surgery, diagnostic procedures, and treatment related to acquired fibrinogen deficiency aimed at reducing blood loss and transfusion requirements in the perioperative period were searched. After screening the titles and abstracts, the articles were examined, and articles that addressed the listed topics were selected. An additional manual search was performed from the reference lists of the included studies.

\section{Results and Discussion}

\subsection{Search Results}

The initial database search retrieved 369 articles, from which 87 matched the inclusion criteria and were included in the analysis. An additional 59 articles were included after a manual search.

\subsection{Physiology of Fibrinogen}

Fibrinogen (coagulation factor I) is a soluble, 340-kDa glycoprotein consisting of $2 \mathrm{~A} \alpha$, $2 \mathrm{~B} \beta$, and $2 \gamma$ polypeptide chains assembled into hexametric complexes. It is primarily synthesised in hepatocytes and circulates in the plasma at a concentration of $2-5 \mathrm{~g} / \mathrm{L}$ [2]. It has the highest concentration amongst all the coagulation factors. The plasma half-life is 3-5 days. It is involved in a number of different physiological and pathophysiological functions [2,29]. The mechanisms that regulate these interactions are still largely undetermined. 
As an acute-phase response protein, fibrinogen increases several-fold during inflammation or tissue damage [2]. During acute inflammation, a rapid fibrinogen increase is a result of enhanced fibrinogen synthesis due to upregulated fibrinogen gene expression in response to mediators of the acute-phase inflammatory response-specifically, interleukin (IL)-6 and glucocorticoids [30]. Plasma fibrinogen levels have been associated with the presence and severity of coronary artery disease, suggesting that fibrinogen is involved in the pathogenesis and progression of coronary artery disease [31-33].

Fibrinogen is a substrate for clot formation. Being the substrate makes it different from other coagulation factors, which are mainly enzymes and have catalytic roles. The consumption of fibrinogen by clot formation may be one of the main reasons why its depletion during severe bleeding or consumptive coagulopathy occurs before the depletion of other factors and platelets.

Fibrinogen has an essential role in primary and secondary haemostasis, as well as fibrinolysis. A simplified scheme of haemostasis can be seen in Figure 1. In primary haemostasis, endothelial injury immediately initiates platelet activation. Fibrinogen binds to activated GPIIb/IIIa receptors on platelets and, thus, bridges platelets, enhances platelet aggregation, and ultimately, forms a platelet plug. Depending on the severity and location of the endothelial damage, a secondary haemostasis is usually initiated simultaneously with the primary haemostasis.

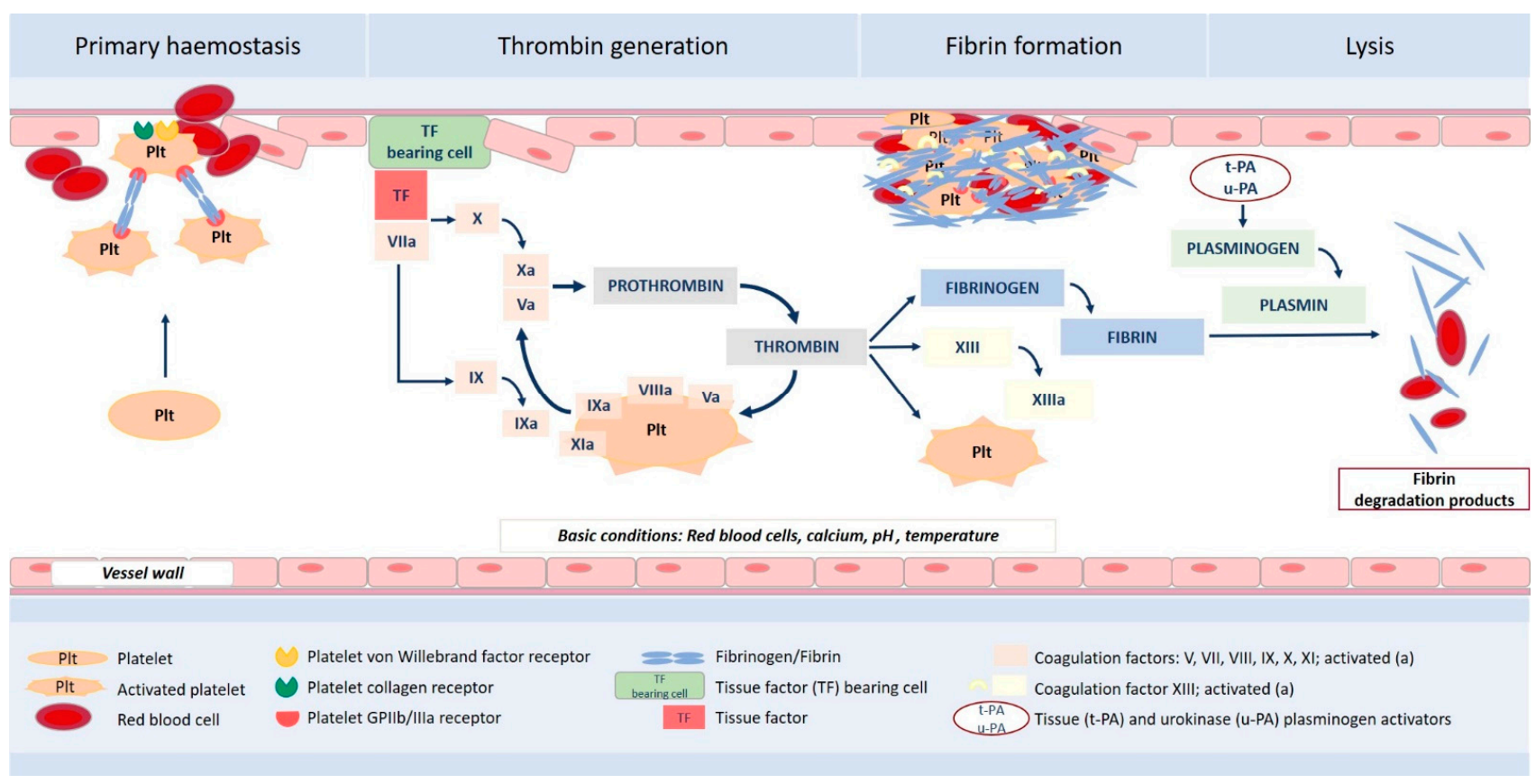

Figure 1. Scheme of haemostasis. Primary haemostasis is initiated with exposure of the subendothelial collagen to blood. It initiates platelet adhesion to the injured vessel wall with von Willebrand factor receptors and collagen receptors, leading to platelet activation. Fibrinogen binds to platelet GPIIb/IIIa receptors, bridges platelets, and enhances platelet aggregation. As a result, a primary platelet plug forms. The platelet plug is further modified and stabilised by fibrin due to the coagulation in the secondary haemostasis. The coagulation process occurs when tissue factor (TF)-bearing cells are exposed to blood. TF binds factor VII in the plasma and forms the TF/VIIa complex, which activates factors X and IX. Xa, in combination with factor Va, transforms small amounts of prothrombin into thrombin. This thrombin amplifies the initial coagulation signal activating platelets and factors V, VIII, and XI. This process generates a large amount of thrombin. Thrombin cleaves fibrinogen to fibrin and activates factor XIII and the platelets. Fibrin polymerises and form the fibrin network. Red blood cells, white blood cells, and platelets become incorporated into its structure. Activated factor XIII crosslinks fibrin polymers. The result is the formation of a haemostatic fibrin clot. Fibrinolysis dissolves the fibrin clot. Upon activation by the tissue plasminogen activator (t-PA) and urokinase plasminogen activator ( $\mathrm{u}-\mathrm{PA})$, plasminogen is converted into plasmin, which cleaves fibrin to fibrin degradation products. 
An activated coagulation system leads to the formation of fibrin that stabilises the primary platelet plug and, finally, stops the bleeding. The place of fibrinogen in the coagulation system is in the last steps of the coagulation cascade. Namely, the activation of coagulation pathways begins with the formation of a tissue factor (TF)/factor VIIa complex, which leads to factor $X$ activation, which converts prothrombin (factor II) into thrombin (factor IIa) [34]. Thrombin cleaves fibrinogen to insoluble fibrin monomers and activates factor XIII and the platelets. Fibrin polymerises and forms the fibrin network. As the clot network forms, red blood cells (RBCs), white blood cells, and platelets become incorporated into its structure. Activated factor XIII (XIIIa) crosslinks fibrin polymers, stabilising and improving the clot strength and elasticity [15]. Thus, fibrinogen, platelets, and factor XIII are critical components for clot formation, amplification, and strength. The clot structure and stability are strongly influenced by the conditions present during fibrin generation: the concentrations of procoagulants, anticoagulants, fibrinogen-binding proteins, $\mathrm{pH}$, temperature, blood and vascular cells, and the availability of thrombin, calcium, and negatively charged phospholipid membranes [2,35]. Stability also relies on the fibrin fibre diameter and the architecture of the fibrin network.

Activation of the coagulation and clot formation is in balance with the fibrinolytic system. Fibrinolysis is an enzymatic process that degrades the fibrin clot into fibrin degradation products (FDPs) [36]. This prevents the unnecessary accumulation of intravascular fibrin, limits the clot size, and provides the removal of thrombi. Imbalance between thrombogenic and antithrombogenic mechanisms may lead to bleeding or thrombosis [35,37].

The fibrinolytic system is activated by thrombin. A series of cascading reactions leads to the conversion of plasminogen into the active plasmin, which lyses fibrin [38]. Plasminogen is activated with the tissue plasminogen activator ( $t-P A)$ and urokinase plasminogen activator (u-PA). The reactions are controlled by a number of cofactors, signalling molecules, and inhibitors. The extent of fibrinolysis is determined by the structure and strength of the clots [2]. The fibrin fibre density, factor XIII crosslinking, incorporated platelets, and RBCs reduce the clot permeability and make clots more resistant to lysis [38]. Fragile clots are more susceptible to fibrinolysis and bleeding.

Fibrinogen provides haemostasis as the fibrin precursor and, by bridging activated platelets but, also, by the proper disposition of erythrocytes, macrophages and fibroblasts around a wound [39]. All of these processes are important to stop the bleeding, improve wound healing, ensure tissue regeneration, and prevent pathogen invasion and infection [35].

\subsection{Mechanisms of Plasma Fibrinogen Disorder and Preservation during Cardiac Surgery}

Cardiac surgery is specific due to the invasiveness of the procedures, the need for the high-dose anticoagulation, and the exposure to CPB. It creates a complex milieu where multiple factors and different mechanisms lead to a decrease in the plasma fibrinogen concentration or function. Different mechanisms overlap and affect each other. The main causes of fibrinogen disorder in cardiac surgery using CPB include haemodilution, consumption, and blood loss.

The most common cause of decreased fibrinogen levels is haemodilution due to the $\mathrm{CPB}$ priming volume, infusion of fluids, and transfusion of blood products without or with low-fibrinogen concentrations $[4,10,14,40]$. Haemodilution increases the clot permeability and decreases the resistance to fibrinolysis. The extent of haemodilution depends on the volume and type of fluids administered and on the total patient blood volume. The priming volume is determined by the type of CPB and is usually about $30 \%$ of the adult blood volume [41]. The volume of fluid applied during the induction of anaesthesia and for the priming of conventional CPB may exceed $2000 \mathrm{~mL}$. As the priming volume is set for each type of $\mathrm{CPB}$ circuit, the extent of haemodilution depends on the relationship between the priming volume of a particular CPB set and the total blood volume for each patient individually. 
Different types of fluids impair haemostasis to different extents. Priming with hydroxyethyl starch (HES 130/0.42) reduces the fibrinogen concentration and clot strength more than gelatines [42]. The effect of colloids on coagulation has not yet been fully elucidated. It is known that, in addition to the dilution effect, HES and gelatines may impair haemostasis through their interactions with the function of the vWF and with factor VIII, through interactions with fibrin formation and platelet function [43,44]. It is not new, but colloids will certainly be the subject of future research, and a few clues are given here. HES cause a decrease of factor VIII and vWF, which can lead to decreased thrombin generation and, consequently, fibrin formation, impaired platelet adhesion, and aggregation [45,46]. The interaction of factor XIII with the polymers is reduced, which can reduce the clot strength and make it susceptible to fibrinolysis [47]. In addition, cellular changes, platelet surface coating of HES molecules, and decreased GPIIb/IIIa receptor activity may cause decreased fibrinogen binding and platelet aggregation [45]. Analyses showed that gelatines have a greater influence on the structure and mechanics of clots and HES on platelet functions, which may differently influence the extent of coagulation disturbances [44]. Studies have shown that lower molecular weight tetrastarches impairs coagulation more than gelatines according to ROTEM tests [42,48], but differences in the effect of coagulation on postoperative blood loss could not be demonstrated $[42,48,49]$. One can speculate about the cause of this-for example, whether it is due to the nature of the test itself.

The reduction of haemodilution is recommended as part of a blood conservation strategy in recent guidelines, and the use of low-molecular weight starches in priming and non-priming solutions is not recommended [50]. Strategies that can minimise haemodilution may include the use of miniaturised $\mathrm{CPB}$ circuits (mini-CPB), retrograde autologous priming of the $\mathrm{CPB}$, and ultrafiltration [50,51]. As a measure of blood conservation during $\mathrm{CPB}$, acute normovolemic haemodilution [51], although causing haemodilution and lower haematocrit during $\mathrm{CPB}$, has been shown to significantly improve the fibrinogen concentration after reinfusion [52].

Surgical trauma, blood contact with artificial surfaces, and air in the CPB circuit, oxygenator, reservoir, and other parts of the $\mathrm{CPB}$ cause activation of the coagulation system, platelets, and inflammatory system. This creates complex interactions that result in a consumption of all the coagulation factors, including fibrinogen and platelets. As a result, fewer potential clot-forming components are available after $\mathrm{CPB}$ [53], and the perioperatively clotting activity is reduced by $10-36 \%$ [7].

Tissue factor (TF) release due to extensive tissue injury is a major determinant of large thrombin generation that results in the progressive consumption of soluble coagulation factors and fibrinogen [13]. Thus, the decrease in clotting factors, platelet count, and function are present even before $\mathrm{CPB}$ [7]. To prevent blood clotting within the CPB circuit, anticoagulation is necessary. Unfractionated heparin (UFH) is most commonly used. UFH binds to antithrombin III and accelerates its inhibition of thrombin and factor $X$. The inhibition of thrombin by UFH stops the conversion of fibrinogen to fibrin. At the end of $\mathrm{CPB}$, heparin is antagonised by protamine sulphate. The coagulation process then continues leading to the further consumption of coagulation factors and fibrinogen. Despite heparin anticoagulation, some activation of coagulation still occurs due to the action of TF. It may result in continuous consumptive coagulopathy during CPB. This is particularly pronounced in highly invasive surgical procedures such as aortic replacement surgery, where a larger amount of TF is released [54]. Blood accumulated in the pericardial and pleural spaces contains large amounts of TF, cell debris, fibrin clots, fat, and other microparticles and proinflammatory mediators. This blood is usually returned to $\mathrm{CPB}$ through cardiotomy suction. The direct re-administration of shed blood from the surgical field or residual CPB volume at the end of CPB generates a considerable amount of thrombin and may contribute to systemic inflammation and bleeding [13,55]. Excessive thrombin generation during cardiac surgery causes bleeding due to reduced fibrinogen production because of the fibrinogen consumption and thrombin-mediated activation of the anticoagulation system, on the one hand [56] and, on the other hand, due to increased 
fibrin degradation because of thrombin-activated fibrinolysis [57]. Namely, thrombin via thrombomodulin activates the protein $C$ anticoagulation pathway, leading to a t-PA increase. T-PA induces the conversion of plasminogen to plasmin, which degrades fibrin. This can lead to hyperfibrinolysis and the rapid dissolution of clots.

Different methods are available for filtering and washing shed blood. They are incorporated into mini-CPB and various cell salvage devices. The use of cell salvage or other methods to avoid the direct retransfusion of shed blood, instead of cardiotomy suction, may reduce the activation of the coagulation [55,58-60]. However, fibrinogen and other coagulation factors, proteins, and platelets are lost from the blood by the processes of washing and filtering and the concentration of RBCs [60,61]. Retransfusion of large volumes of cell-salvaged blood can induce progressive plasma dilution and impair coagulation [41,50], leading to postoperative bleeding [62]. The extent of these processes varies between different methods and filtration devices [63-66]. Furthermore, to minimise the blood/air interface and activation of coagulation and platelets, the use of a closed CPB system may be considered [50].

Coagulation and inflammation are closely linked through humoral and cellular components, including enzymes of the coagulation and fibrinolytic system, including the tissue factor, which initiates thrombin generation. In a study examining the effects of steroids on coagulation, it was shown that reducing the inflammatory response to surgery and $\mathrm{CPB}$ with steroid therapy can reduce thrombin generation and attenuate fibrinolysis and possibly affect the preservation of haemostasis [67].

The adhesion of fibrinogen to artificial surfaces not only leads to the consumption of fibrinogen by activating coagulation but also reduces its level by deposition on foreign materials. Since this binding is competitive with other plasma proteins, primarily albumin, modification of the compositions of priming solutions may affect the extensiveness of this process. The use of biocompatible surfaces may also reduce fibrinogen deposition. While some studies indicate positive effects of certain biocompatible surfaces on coagulation, blood loss, and the transfusion requirements [68], others did not show a significant effect on either the fibrinogen level or function [69].

Consumptive coagulopathy and hypofibrinogenemia may occur before surgery in some pathological conditions, such as acute aortic dissection [70-72]. In this case, the contact between the blood and the false lumen of the dissected aorta activates the coagulation system and consumes a large amount of coagulation factors and fibrinogen even before surgery.

Thrombin is also a direct activator of the fibrinolytic system. Fibrinogen degradation, and the formation of FDPs that further affect fibrin formation, may contribute to the reduction of fibrinogen levels and the function [14]. The extent of fibrinolysis can be limited by the use of antifibrinolytics. The routine use of antifibrinolytics to prevent and/or to treat hyperfibrinolysis is strongly recommended $[50,73]$. To reduce bleeding and the transfusions of blood products, synthetic lysine analogues tranexamic acid (TXA) or $\varepsilon$-aminocaproic acid (EACA) are commonly used during cardiac surgery. Both drugs competitively inhibit the activation of plasminogen to plasmin, and TXA at much higher concentrations acts as a non-competitive inhibitor of plasmin.

CPB activates the plasma kallikrein-kinin system. This system consists of three serine proteinases: coagulation factors XII and XI and plasma pre-kallikrein and the cofactor high molecular weight kininogen. These proteins are grouped together as the contact pathway of coagulation that responds to contact with artificial materials and invasive pathogens [74]. Activation of this system leads to the activation of factor XI, thereby initiating blood coagulation and the generation of proinflammatory products such as bradykinin. Bradykinin, acting through its $B_{2}$ receptor, stimulates the release of endothelial t-PA [75]. Active t-PA catalyses the conversion of plasminogen to plasmin, which degrades fibrin. Since the kallikrein-kinin system is activated during CPB and endogenous bradykinin contributes to fibrinolysis and inflammation, the effect of a bradykinin $\mathrm{B}_{2}$ receptor antagonist on fibrinol- 
ysis was investigated but was not shown to be effective in reducing postoperative bleeding as EACA [76].

Hypothermia, acidosis, and low calcium levels may impair the enzymatic process of coagulation and determine the different degrees of coagulopathy and bleeding.

There is always the possibility of incomplete heparin antagonism and of the rebound heparin effect [77]. On the other hand, protamine in excess possesses anticoagulation properties and may cause bleeding [78].

Blood loss, whether from surgical sources or due to the effect of heparin or excess protamine, coagulation factor depletion, thrombocytopenia, platelet dysfunction, or hyperfibrinolysis, may cause or aggravate fibrinogen loss. In addition, fibrinogen consumption exceeds fibrinogen synthesis during major bleeding. The risk of bleeding is even higher if there is an urgency of procedure, complex surgery, redo surgery, prolonged CPB time, advanced age, the female gender, small body surface area, anaemia, patient comorbidities, and preoperative antiplatelets and anticoagulant medication [7,25,50,79-81].

\subsection{Kinetics of Plasma Fibrinogen in Cardiac Surgery}

Most cardiac surgery patients have normal or slightly elevated preoperative fibrinogen levels. Elevated fibrinogen concentrations may be associated with the age and chronic proinflammatory state due to cardiovascular disease in these patients [31,32]. Preoperative hypofibrinogenemia is rare. Decreased preoperative fibrinogen concentrations can be expected in patients with acute aortic dissection [70-72].

Most commonly, fibrinogen disorders in cardiac surgery are intraoperatively acquired, and fibrinogen levels decrease significantly during CPB [4,10,40]. Immediately after the procedure, a decrease of $29-40 \%$ compared to the preoperative values was observed $[9,14,40,79]$. According to Erdoes et al., the incidence and magnitude of fibrinogen disorder is more pronounced with the complexity of the procedure, longer CPB time, larger CPB priming volume, and lower preoperative fibrinogen level [4]. The largest decrease, to $64.3 \pm 7 \%$ of the baseline, was recorded after CPB. In their study, a decrease from the preoperative fibrinogen level to the time of heparin reversal from a median of $3.0 \mathrm{~g} / \mathrm{L}$ to $2.15 \mathrm{~g} / \mathrm{L}, 2.9 \mathrm{~g} / \mathrm{L}$ to $1.71 \mathrm{~g} / \mathrm{L}$, and $2.7 \mathrm{~g} / \mathrm{L}$ to $1.46 \mathrm{~g} / \mathrm{L}$ for CABG, aortic valve replacement, and ascending aorta replacement, respectively, was observed. Additionally, they found that fibrinogen was better preserved when minimally invasive extracorporeal circulation (MiECC) was used compared to conventional CPB. Due to less haemodilution, these patients had significantly higher postoperative plasma fibrinogen levels than patients perfused with conventional CPB. The authors noted that the use of specific perfusion circuits and priming fluids, antifibrinolytics, shed blood recovery, and surgical haemostasis techniques may have influenced the fibrinogen kinetics. Nishi et al. investigated the incidence of hypofibrinogenemia and predictors for hypofibrinogenemia [11]. They found fibrinogen levels $\leq 1.5 \mathrm{~g} / \mathrm{L}$ at the end of CPB in $50.2 \%$ of patients undergoing aortic surgery, $26.5 \% \mathrm{CABG}$, and $22.8 \%$ valvular surgery and identified the preoperative fibrinogen levels, redo surgery, and perfusion time as predictors for intraoperative hypofibrinogenemia. The preoperative plasma fibrinogen level cut-off value for predicting the intraoperative fibrinogen level $\leq 1.5 \mathrm{~g} / \mathrm{L}$ was $3.0 \mathrm{~g} / \mathrm{L}$ (sensitivity $72.4 \%$, specificity $73.4 \%$, PPV 57.0\%, and NPV $84.5 \%$ ). In their study, hypofibrinogenemia was particularly common in patients with aortic surgery, with preoperative fibrinogen concentrations $\leq 2.5 \mathrm{~g} / \mathrm{L}$. The reasons for this may be hypothermia, a long duration of CPB, and a large and invasive surgical field.

After surgery, in the absence of bleeding, the fibrinogen concentration recovers spontaneously within the next few or $24 \mathrm{~h}[4,40,70,79,82]$. Erdoes et al. reported that the plasma fibrinogen concentration increases at a nearly constant rate of approximately $0.08 \mathrm{~g} / \mathrm{L}$ per hour [4]. Due to the proinflammatory response to surgery and CPB, the fibrinogen levels usually rise above the preoperative levels and may exceed the upper reference values in the early postoperative days [40,70]. 


\subsection{Fibrinogen Deficiency Diagnosis}

Bleeding during cardiac surgery is caused by multiple, often interactive, factors, and it is difficult to separate the effects of different factors and mechanisms on bleeding in each individual patient in everyday clinical practice. Fibrinogen can drop to critical levels very fast during cardiac surgery. Therefore, a rapid diagnosis of fibrinogen disorder is needed to enable early and targeted therapy.

Conventional laboratory fibrinogen assays, the Clauss method, measure fibrinogen concentrations in the laboratory. They are generally time-consuming, performed in plasma samples, and do not add contribution of the cellular components and information about platelet functions. Clauss assays are not valid during CPB [83].

Viscoelastic tests (VETs), thromboelastography $\left(\mathrm{TEG}^{\circledR}\right)$, and rotational thromboelastometry $\left(\mathrm{ROTEM}^{\circledR}\right)$ provide information about the dynamics and quality of clotting from coagulation initiation to clot lysis. These are point-of-care tests in whole-blood samples. In 10-20 $\mathrm{min}$, it is possible to estimate the speed of clotting, clot strength, and the existence of fulminant fibrinolysis. In contrast to the standard coagulation tests, VETs can be used during $\mathrm{CPB}$, allowing blood products to be prepared for administration immediately after CPB when required [83-86]. In this way, VETs not only enable a rapid assessment of coagulation but, also, more targeted and earlier interventions than conventional tests.

Different VET assays synergistically assess specific parts of haemostasis. Clot-related tests are able to detect fibrinogen disorder, platelet dysfunction, and hyperfibrinolysis. The kinetics of fibrin polymerisation and crosslinking are expressed by the alpha angle. The alpha angle is the angle between the line in the middle of the trace and tangential to the body of the VET trace. A reduced angle indicates a lack of fibrinogen. The strength or firmness of the clot is expressed by the amplitudes in the extrinsic thromboelastometry (EXTEM) and fibrin-based thromboelastometry tests (FIBTEM). Amplitudes at different time points are described by A5-A30 (A5 is the amplitude 5 min after coagulation time (CT), and A10 is the amplitude $10 \mathrm{~min}$ after $\mathrm{CT}$ ). The maximal clot strength is expressed as the maximum amplitude (MA) and the maximum clot firmness (MCF) for the TEG and ROTEM, respectively. A low EXTEM MCF indicates a weak clot as a result of decreased fibrinogen, a decreased platelet count and/or function, fibrin polymerisation disorders, or low activity of factor XIII. An example of the ROTEM test results can be seen in Figure 2.

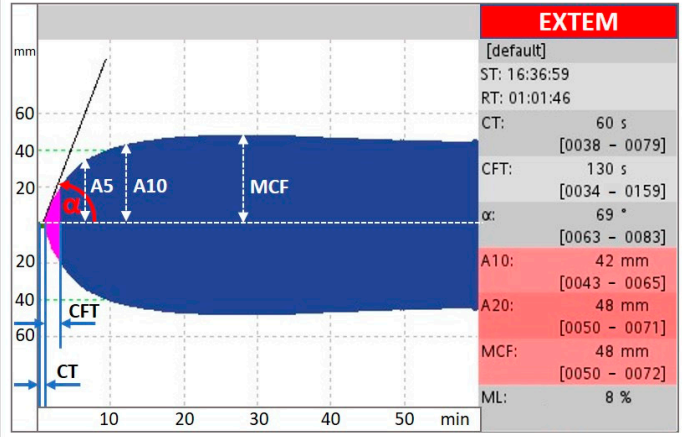

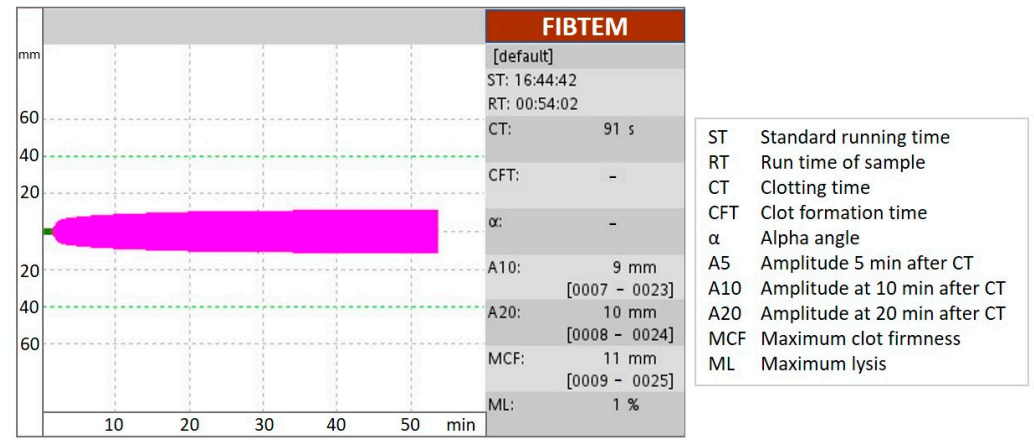

Figure 2. The results of the ROTEM test performed at the end of CABG surgery in a patient with bleeding. Low amplitudes (A10, A20, and MCF) in the EXTEM test suggest a problem with fibrinogen and/or the platelets (A). Low amplitudes (A10, A20, and MCF) in the EXTEM test indicate reduced fibrinogen levels and/or impaired fibrin polymerisation (B).

To assess the contribution of fibrin to the total clot firmness, functional fibrinogen (FF) is intended for the TEG device, while FIBTEM and FIBTEM PLUS are intended for the ROTEM device. To eliminate the contribution of platelets to clot strength, different inhibitors or their combinations are used for each of these tests. A glycoprotein IIb/IIIa inhibitor is used in the FF test, cytochalasin D is used in the ROTEM test, and cytochalasin 
$\mathrm{D}$ and the glycoprotein IIb/IIIa receptor inhibitor tirofiban are used in the FIBTEM PLUS test. These inhibitors differ in their ability to exclude the contribution of platelets to the clot strength, and the differences are greater at higher platelet levels [87]. Incomplete platelet inactivation can lead to falsely high MCF and to overestimated functional fibrin polymerisation. This is clinically important, as it may cause the necessary fibrinogen supplementation to be missed or to be administered in inadequate doses. The dual plateletinhibiting assays ensure a more efficient elimination of the platelet component to the clot strength at higher platelet levels compared to FF in the TEG and FIBTEM [88]. All three tests may be equally useful in assessing clot strength at low platelet counts, while FIBTEM PLUS has an advantage in assessing clot strength at high platelet counts.

A deficiency in fibrinogen leads to decreased clot firmness, which is expressed as reduced clot amplitudes (A5, A10, and MCF). The Clauss fibrinogen concentration correlates with the alpha angles and MA in the TEG [89] and FIBTEM MCF [4,7,90,91] and A10 [86,90,92,93], as well as A5, in ROTEM [94]. Erdoes et al. found that a FIBTEM A10 of $10 \mathrm{~mm}$ or less, measured on CPB prior to weaning, allows the identification of patients who will have fibrinogen levels below or within the range of 1.5-2.0 g/L after CPB [85]. This can be even shorter if A5 is used and, thus, may shorten the turnaround time and improve transfusion management [92,94].

Although the plasma fibrinogen concentration and clot firmness usually correlate, they do not represent the same. The plasma fibrinogen concentration is a measure of quantity, and clot firmness is a measure of the effect achieved by the quantity and quality of fibrinogen molecules. Modified plasma concentrations and structural properties affect clot formation, strength, permeability, and lysis resistance.

The correlation between the plasma fibrinogen levels and TEG and ROTEM parameters may be affected with perioperative changes in haematocrit [86,95], fibrinogen concentrate supplementation [90,93], and synthetic colloids administration [96]. Ogawa et al. showed that FIBTEM MCF increases with a lower haematocrit, while plasma fibrinogen concentrations do not change with different haematocrit levels [95]. Additionally, a lower haematocrit gives a better correlation between FIBTEM-MCF and plasma fibrinogen. The reason for this is that FIBTEM MCF is made from whole blood and considers the contribution of red blood cells as part of the strength of the clot. It is speculated that fibrin spreads through the gaps between erythrocytes during clot formation, and therefore, a lower haematocrit may be more suitable for fibrin polymerisation [95]. In contrast, if a large number of RBC are tightly integrated into the fibrin network, the fibre density decreases, resulting in a weaker clot [97]. This effect does not occur in haemodiluted patients in whom, in addition to low haematocrit, the fibrinogen levels are also reduced [95]. After therapy with the fibrinogen concentrate, the correlation of the plasma fibrinogen level with the clot firmness is reduced, and the reasons for these findings are unclear [93]. This means that the administration of fibrinogen concentrates increases both - the plasma fibrinogen concentration and clot firmness, but the relative increase in clot firmness is smaller compared to the increase in fibrinogen concentration. One explanation for this may be the quality of the molecules found in the fibrinogen concentrate and their ability to clot. The effect of colloids on coagulation has already been discussed. Further investigation is needed to clarify these findings and to examine their importance in the correct diagnosis and therapeutic decision-making.

Other coagulation point-of-care tests based on thromboelastometry, thromboelastography, or sonorheometry are still being investigated [98-101].

The existing guidelines recommend VETs and/or standard coagulation tests to identify the mechanism of bleeding and therapeutic algorithms based on coagulation monitoring to treat bleeding $[50,73]$. The use of blood management protocols based on VETs compared to conventional coagulation tests has been shown to reduce postoperative blood loss and allogeneic blood transfusions [102-105]. 


\subsection{Association between Fibrinogen Plasma Concentration and Bleeding}

Clarifying the relationship between perioperative fibrinogen levels and bleeding may serve to identify patients with an increased risk of bleeding and is essential for determining the fibrinogen substitution.

Studies have shown an association between perioperative plasma fibrinogen concentrations and postoperative bleeding and/or the need for allogeneic blood products (Table 1).

Waldén et al. found that a preoperative fibrinogen plasma concentration of less than $2.5 \mathrm{~g} / \mathrm{L}$ was associated with increased postoperative bleeding but not with RBC transfusion [106]. The same study, in the CABG subgroup showed an association of a high preoperative fibrinogen concentration with RBC transfusion. Rafiq et al. confirmed the association of low preoperative fibrinogen levels with postoperative bleeding [107]. Fröjd at al. identified low preoperative plasma fibrinogen levels as an independent risk factor of re-exploration for bleeding [25]. They also found high preoperative fibrinogen concentration as an independent risk factor for postoperative mortality and confirmed the association between re-exploration for bleeding and postoperative morbidity and mortality. Two groups of authors, Gielen et al. [108] in a meta-analysis and Kindo et al. [79] in a prospective observational study, found correlations between pre- and postoperative low fibrinogen levels and bleeding. Charbonneau et al. found that preoperative fibrinogen levels below $1.5 \mathrm{~g} / \mathrm{L}$ and above $3 \mathrm{~g} / \mathrm{L}$ were associated with an increase in RBC transfusion in elective cardiac surgery, and a fibrinogen level $>3.8 \mathrm{~g} / \mathrm{L}$ was an independent risk factor for RBC transfusion [109]. They also showed that gradients between the preoperative and immediate postoperative fibrinogen levels $>1.1 \mathrm{~g} / \mathrm{L}$ were predictive for RBC transfusion. Mazur et al. assessed the preoperatively fibrinogen levels and plasma clot properties (tissue plasminogen activator (tPA)-induced clot lysis time, clot permeability, fibrinolysis inhibitors, calibrated automated thrombogram, and platelet activation markers) [110]. They found that preoperative fibrin clot susceptibility to lysis was a modulator of postoperative blood loss and that it affected the postoperative rate of platelet transfusion. The preoperative fibrinogen levels were normal but were inversely correlated with the chest tube output. Yang et al. found that preoperative serum fibrinogen level were associated with the risk of postoperative acute kidney injury after cardiac valve replacement surgery [111]. 
Table 1. Studies investigating the association between perioperative fibrinogen concentrations and bleeding.

\begin{tabular}{|c|c|c|c|c|c|c|c|}
\hline Author (Year) & Type of Study & Type of Surgery & Number of Patients & $\begin{array}{l}\text { Time Point of } \\
\text { Fibrinogen } \\
\text { Determination }\end{array}$ & Method & $\begin{array}{l}\text { Fibrinogen } \\
\text { Concentration }\end{array}$ & Associated Outcome \\
\hline Waldén (2015) [106] & $\begin{array}{l}\text { Prospective } \\
\text { observational }\end{array}$ & $\begin{array}{l}\text { CABG } \pm \text { valve, valve, } \\
\text { adult congenital, } \\
\text { arrhythmia operations }\end{array}$ & 1954 & Preoperative & Clauss & $<2.5 \mathrm{~g} / \mathrm{L}$ & $\begin{array}{l}\text { Excessive bleeding } \\
>1000 \mathrm{~mL} / 12 \mathrm{~h}\end{array}$ \\
\hline Rafiq (2016) [107] & $\begin{array}{c}\text { Prospective, } \\
\text { observational }\end{array}$ & Elective, urgent $\mathrm{CABG}$ & 170 & Preoperative & Clauss & $<2.5 \mathrm{~g} / \mathrm{L}$ & $\begin{array}{l}\text { Excessive bleeding } \\
>1000 \mathrm{~mL} / 18 \mathrm{~h}\end{array}$ \\
\hline Fröjd (2016) [25] & $\begin{array}{l}\text { Retrospective, } \\
\text { observational }\end{array}$ & Cardiac surgery with $\mathrm{CPB}$ & 5345 & Preoperative & Clauss & Low & Re-exploration for bleeding \\
\hline Gielen (2014) [108] & $\begin{array}{l}\text { Review and } \\
\text { meta-analysis }\end{array}$ & $\begin{array}{l}\text { Mixed cardiac surgery } \\
\text { procedures }\end{array}$ & 5972 & $\begin{array}{l}\text { Preoperative; } \\
\text { Postoperative }\end{array}$ & $\begin{array}{l}\text { Clauss, Clauss-like } \\
\text { or not reported }\end{array}$ & Low & Blood loos \\
\hline Kindo (2014) [79] & $\begin{array}{l}\text { Prospective, } \\
\text { observational }\end{array}$ & $\begin{array}{c}C A B G \pm \text { valve, valve } \pm \\
\text { thoracic aorta surgery }\end{array}$ & 1956 & $\begin{array}{c}\text { Preoperative; } \\
\text { Postoperative (on } \\
\text { admission to the ICU) }\end{array}$ & Clauss & $\begin{array}{l}\text { Postoperative } 2.1 \pm 0.8 ; \\
\quad \text { Cut-off } 2.2 \mathrm{~g} / \mathrm{L}\end{array}$ & Excessive bleeding \\
\hline Charbonneau (2020) [109] & $\begin{array}{l}\text { Retrospective, } \\
\text { observational }\end{array}$ & Elective cardiac surgery & 476 & Preoperative & Clauss & $\begin{array}{c}<1.5 \mathrm{~g} / \mathrm{L} ;>3 \mathrm{~g} / \mathrm{L} ; \\
\text { Fibrinogen gradient }> \\
1.1 \mathrm{~g} / \mathrm{L}\end{array}$ & $\mathrm{RBC}$ transfusion \\
\hline Mazur (2019) [110] & $\begin{array}{l}\text { Prospective, } \\
\text { observational }\end{array}$ & $\begin{array}{l}\text { Aortic valve replacement, } \\
\text { Bentall procedure }\end{array}$ & 77 & Preoperative & Clot lysis time & $91 \min (69-102)$ & $\begin{array}{l}\text { Postoperative blood loss } \\
\quad \geq 600 \mathrm{~mL} \text { after } 12 \mathrm{~h}\end{array}$ \\
\hline Yang (2020) [111] & $\begin{array}{l}\text { Retrospective, } \\
\text { observational }\end{array}$ & $\begin{array}{l}\text { Valve replacement } \\
\text { surgery } \pm \text { others }\end{array}$ & 3459 & Preoperative & Clauss & High & Acute kidney injury \\
\hline Essa (2018) [27] & $\begin{array}{l}\text { Retrospective, } \\
\text { observational }\end{array}$ & $\begin{array}{l}\text { Elective, urgent, } \\
\text { emergency, CABG } \pm \\
\text { valve, valve, heart } \\
\text { transplantations }\end{array}$ & 2403 & $\begin{array}{c}\text { Preoperative; } \\
\text { Postoperative (on } \\
\text { admission to the ICU) }\end{array}$ & Clauss & $\begin{array}{l}\text { Preoperative } 2.8 \pm 0.9 \\
\text { Postoperative } 2.0 \pm 0.6\end{array}$ & Bleeding, re-exploration \\
\hline Pillai (2014) [9] & $\begin{array}{l}\text { Prospective, } \\
\text { observational }\end{array}$ & $\mathrm{CABG} \pm$ valve, valve & 250 & $\begin{array}{l}\text { Postoperative (post } \\
\text { CPB) }\end{array}$ & Clauss & $2.95 \pm 1.1$ & $\begin{array}{l}\text { Blood loss } / 24 \mathrm{~h} \text {, blood } \\
\text { transfusions }\end{array}$ \\
\hline Yang (2013) [112] & $\begin{array}{l}\text { Retrospective, } \\
\text { observational }\end{array}$ & Cardiothoracic surgery & 391 & $\begin{array}{l}\text { Postoperative (on } \\
\text { admission to the ICU) }\end{array}$ & Clauss & Low & $\begin{array}{c}\text { Chest drain blood loss within } \\
1 \mathrm{~h} \text { of measurement } \\
\geq 3 \mathrm{~mL} / \mathrm{kg} / \mathrm{h}\end{array}$ \\
\hline
\end{tabular}


Table 1. Cont

\begin{tabular}{|c|c|c|c|c|c|c|c|}
\hline Author (Year) & Type of Study & Type of Surgery & Number of Patients & $\begin{array}{l}\text { Time Point of } \\
\text { Fibrinogen } \\
\text { Determination }\end{array}$ & Method & $\begin{array}{l}\text { Fibrinogen } \\
\text { Concentration }\end{array}$ & Associated Outcome \\
\hline Kawashima (2016) [113] & Retrospective & $\begin{array}{l}\text { Cardiac surgery } \\
\text { procedures }\end{array}$ & 215 & $\begin{array}{l}\text { Postoperative (at the } \\
\text { rewarming of } \mathrm{CPB} \text { ) }\end{array}$ & Clauss FIBTEM A10 & $\begin{array}{c}<1.5 \mathrm{~g} / \mathrm{L} \text { and FIBTEM } \\
\mathrm{A} 10<6 \mathrm{~mm} ; \geq 1.5 \mathrm{~g} / \mathrm{L} \\
\text { and FIBTEM A10 < } \\
\mathrm{mm}\end{array}$ & $\begin{array}{l}\text { Chest tube drainage within } \\
\text { the first } 24 \mathrm{~h}\end{array}$ \\
\hline Kindo (2014) [79] & $\begin{array}{c}\text { Prospective, } \\
\text { observational }\end{array}$ & $\begin{array}{c}\mathrm{CABG} \pm \text { valve, valve } \pm \\
\text { thoracic aorta }\end{array}$ & 1956 & $\begin{array}{l}\text { Postoperative (on } \\
\text { admission to the ICU) }\end{array}$ & Clauss & $2.1 \pm 0.8$ Cut-off $2.2 \mathrm{~g} / \mathrm{L}$ & $\begin{array}{l}\text { Chest tube drainage within } \\
\text { the first } 24 \mathrm{~h}\end{array}$ \\
\hline Karkouti (2013) [114] & $\begin{array}{l}\text { Retrospective } \\
\text { observational }\end{array}$ & $\begin{array}{l}\text { Cardiac surgery } \\
\text { procedures }\end{array}$ & 4606 & $\begin{array}{c}\text { Postoperative (post } \\
\text { CPB) }\end{array}$ & Clauss & $<2.0 \mathrm{~g} / \mathrm{L}$ & Transfusion volume \\
\hline Ranucci (2016) [115] & $\begin{array}{l}\text { Retrospective, } \\
\text { observational }\end{array}$ & $\begin{array}{l}\text { Cardiac surgery } \\
\text { procedures }\end{array}$ & 2800 & $\begin{array}{c}\text { Postoperative (on } \\
\text { admission to the ICU) }\end{array}$ & Clauss & $<2.2 \mathrm{~g} / \mathrm{L}$ & $\begin{array}{l}\text { Chest drain blood loss } \\
>1000 \mathrm{~mL} / 12 \mathrm{~h}\end{array}$ \\
\hline
\end{tabular}

CABG: coronary artery bypass graft. CPB: cardiopulmonary bypass. ICU: intensive care unit. RBC: red blood cell unit. FIBTEM A10: fibrin-based thromboelastometry at 10 min. 
Ranucci et al. reanalysed the data of the existing studies and investigated the positive predictive value (PPV) for excessive bleeding, defined as blood loss greater than $1000 \mathrm{~mL} / 12 \mathrm{~h}$, at different preoperative fibrinogen levels [116]. The authors identified that preoperative fibrinogen levels are poor predictors of severe bleeding after cardiac surgery. They found that fibrinogen levels $<2.5 \mathrm{~g} / \mathrm{L}$ had a PPV of $19 \%$ only.

Other studies have not shown a correlation between preoperative fibrinogen levels and bleeding, except in a univariate analysis where an association was found between elevated fibrinogen levels and RBC transfusions [81,117].

Lower fibrinogen levels measured at the end of CPB [90,113], after CPB $[9,114]$, or at admission to an intensive care unit (ICU) $[27,79,90,112,115,118]$ have been shown to be associated with the intensity of postoperative bleeding $[9,79,90,112,113,115,118]$, with the need for allogeneic blood products $[9,114]$, or with increased re-examinations related to bleeding [27]. Similarly, there was a negative association between FIBTEM MCF and postoperative bleeding [118].

Essa et al. demonstrated that re-explored patients had lower pre- and postoperative fibrinogen levels, more chest tube drainage, received more RBCs transfusions, and that re-exploration was associated with increased morbidity and mortality [27]. In this study, the plasma fibrinogen concentration at the time of ICU admission was the strongest independent predictor of excessive postoperative bleeding. Pillai et al. found that the post-CPB fibrinogen level was an independent predictor of postoperative bleeding and transfusion [9]. Yang et al. showed that the fibrinogen level on admission to the ICU was significantly associated with bleeding at the time of its measurement [112]. Kawashima et al. examined the association of postoperative bleeding with a combined evaluation of the fibrinogen level and fibrin polymerisation during CPB in a four-group Fuji-san classification [113]. They found that fibrinogen levels below $1.5 \mathrm{~g} / \mathrm{L}$ and/or FIBTEM A10 lower than $6 \mathrm{~mm}$ were associated with higher chest tube drainage. Kindo et al. evaluated the perioperative fibrinogen levels and found that fibrinogen levels at the time of ICU admission were an independent risk factor for excessive bleeding and the strongest predictor of postoperative bleeding among the standard coagulation tests used during cardiac surgery [79]. They identified a cut-off value of $2.2 \mathrm{~g} / \mathrm{L}$ at admission to the ICU (sensitivity $67 \%$, specificity $57.2 \%$, PPV 15.1\%, and negative predictive value (NPV) 93.9\%) for severe bleeding. Similarly, Karkouti et al. found that the transfusion volume increased when the fibrinogen levels decreased below $2.0 \mathrm{~g} / \mathrm{L}$ [114]. Ranucci et al. found that fibrinogen levels lower than $2.2 \mathrm{~g} / \mathrm{L}$ were independently associated with severe bleeding [115].

The results of these studies may have been influenced by different definitions of major bleeding, time points for bleeding assessments, variations in patient selection, type and urgency of surgery, presence of preoperative anaemia, differences in transfusion policies between institutions, and study design. Additionally, the presence of other risk factors for bleeding, such as preoperative antiplatelet and anticoagulant drugs, may have affected the results.

In summary, lower perioperative fibrinogen levels correlate with more bleeding and may be independently associated with severe bleeding. Even fibrinogen levels above the lower reference value are associated with bleeding. According to the guidelines for the management of severe perioperative bleeding from the European Society of Anaesthesiology (ESA guidelines), fibrinogen concentrations of less than $1.5-2 \mathrm{~g} / \mathrm{L}$ are considered as hypofibrinogenemia in acquired coagulopathy [73]. The fibrinogen cut-off values in the prediction of postoperative bleeding were very similar in different studies. The strength of the clot may be impaired even at normal fibrinogen concentrations. The clot structure might be more relevant for bleeding risk assessments than the fibrinogen concentration itself. These results confirm that fibrinogen plays a key role in haemostasis and clot formation.

Higher preoperative fibrinogen levels are associated with RBC transfusion and postoperative mortality. The relationship between high preoperative fibrinogen levels and RBC transfusion remains unclear. In a study of Waldén et al., patients with higher fibrinogen levels were older, were more likely to be female, had lower preoperative haemoglobin levels, 
and were more likely to be operated on acutely [106]. All of these factors are well-known risk factors for bleeding and transfusion. In a study of Charbonneau et al., patients with higher fibrinogen levels had higher C-reactive protein (CRP) and the lowest haemoglobin levels. All three factors were associated with inflammation, and the authors suggested that the inflammatory response, activated prior to surgery, could be involved in the perioperative transfusion requirements $[31,109]$. On the other hand, Liu et al. demonstrated an association between the preoperative CRP levels and elevated plasma fibrinogen concentration and less postoperative bleeding after CABG surgery [119]. Yang et al. suggested an acute inflammatory response to tissue injury or infection as causes of preoperative increases in the plasma fibrinogen concentration and consequent increase in the blood viscosity, which may lead to endothelial function impairment, renal tubular hypoperfusion, and acute kidney injury [111].

Postoperative bleeding is of multifactorial aetiology, and the measure of the preoperative fibrinogen level alone does not provide a high PPV for severe bleeding. The risk of fibrinogen-related bleeding should not be determined solely on the basis of the measured fibrinogen levels and its PPV for severe bleeding; the relationship between the fibrinogen levels and the risk of bleeding should be considered in the context of a complex clinical scenario.

\subsection{Fibrinogen Supplementation}

\subsubsection{Sources of Fibrinogen}

There are three different sources of fibrinogen: plasma preparations, cryoprecipitate, and fibrinogen concentrate (FC). Cryoprecipitate and FC are not available in all countries.

The concentration of fibrinogen in fresh frozen plasma (FFP) is low $(1-4 \mathrm{~g} / \mathrm{L})$ and may limit the extent of fibrinogen repletion $[15,120,121]$. Large FFP volumes are often required to correct coagulation disorder due to fibrinogen deficit. This can lead to volume overload and haemodilution [122]. Cryoprecipitate contains a much higher concentration of fibrinogen than plasma (approx. $15 \mathrm{~g} / \mathrm{L}$ ) [15,121]. The average concentration of fibrinogen in plasma and cryoprecipitate can vary significantly between different products and units, meaning that it cannot be precisely dosed, and the increase in patient plasma fibrinogen levels after transfusion cannot be precisely predicted [123]. Furthermore, the preparation of FFP and cryoprecipitate for transfusion takes time and may take more than $60 \mathrm{~min}$ to be administered, thus delaying the necessary treatment. Additionally, a number of safety concerns are associated with these allogeneic blood products.

In contrast, FC contains a standardised dose of fibrinogen (15-20 g/L); with no need for thawing or blood group matching, it can be prepared and administered rapidly, in less than $15 \mathrm{~min}$, can be administered in a smaller volume, and is virally inactivated [15]. A recently published FIBRES Randomised Clinical Trial (RCT) demonstrated the noninferiority of FC compared with cryoprecipitate treatment in patients with severe bleeding and hypofibrinogenemia [124]. Studies focusing on the safety of fibrinogen concentrate suggest that the perioperative administration of FC to patients with bleeding in cardiac surgery is not associated with increased incidences of major adverse cardiac and thromboembolic events and mortality [125-127]. A retrospective study of patients undergoing thoracic aortic surgery found that treatment with FC or cryoprecipitate was not associated with either thromboembolic events or 30-day mortality [128]. A number of studies did not show clinically detectable side-effects of FC infusion [6,10,11,118,129-132].

Given the known effects of allogeneic blood products and the potentially beneficial effects of factor concentrates, the ESA guidelines suggest coagulation factor concentrates for the primary treatment of acquired coagulation factor deficiency, and in cases where FC is not available, cryoprecipitate is suggested [73]. According to the guidelines, plasma transfusion alone is not sufficient to correct hypofibrinogenemia. 


\subsubsection{Timing for Fibrinogen Supplementation}

Low preoperative and postoperative fibrinogen levels have been shown to be associated with postoperative bleeding, which raises the question of whether the prophylactic and/or therapeutic use of fibrinogen can affect the amount of postoperative bleeding and the need for blood transfusions.

It is known that there is no strong evidence that FFP transfusion has a positive effect on morbidity and mortality and may cause harm. There is insufficient literature evaluating cryoprecipitate transfusions in the treatment of perioperative coagulopathy. Many studies have focused on investigating the possible positive effects of FC use in cardiac surgery (Table 2).

There were three studies focused on prophylactic preoperative FC administration. Karlsson et al., in a study published in 2011, demonstrated that a preoperative infusion of $2 \mathrm{~g}$ of FC to low-risk cardiac surgery patients without fibrinogen deficiency or ongoing bleeding resulted in increased plasma fibrinogen levels but without or with minimal changes in the biomarkers reflecting coagulation, fibrinolysis, and platelet function [133]. A study published in 2014 showed that $1 \mathrm{~g}$ of FC administered immediately before CABG surgery reduced postoperative bleeding [130]. After that, in 2015, Jeppsson et al. showed that a preoperative supplementation with $2 \mathrm{~g}$ of FC did not reduce postoperative bleeding in patients with CABG and a low risk of bleeding and preoperative normal fibrinogen levels below $3.8 \mathrm{~g} / \mathrm{L}$ [129]. 
Table 2. Studies evaluating fibrinogen supplementation in adult cardiac surgery.

\begin{tabular}{|c|c|c|c|c|c|c|}
\hline Author (Year) & Type of Study & Type of Surgery & Number of Patients & Timing of Intervention & $\begin{array}{c}\text { Dose of } \\
\text { Fibrinogen/Control } \\
\text { Drug } \pm \text { Target Dose }\end{array}$ & $\begin{array}{l}\text { Associated Outcome } \\
\text { (FC Group) }\end{array}$ \\
\hline Karlsson (2011) [133] & Prospective, randomised & $\begin{array}{c}\text { Elective CABG and } \\
\text { preoperative fibrinogen } \\
\text { level } \leq 3.8 \mathrm{~g} / \mathrm{L}\end{array}$ & FC $(n=10) ;$ Control $(n=10)$ & Preoperative & $2 \mathrm{~g}$ & $\begin{array}{l}\text { No or minimal changes in } \\
\text { biomarkers reflecting coagulation, } \\
\text { fibrinolysis, and platelet function }\end{array}$ \\
\hline Sadeghi (2014) [130] & $\begin{array}{l}\text { Prospective, randomised, } \\
\text { double-blind }\end{array}$ & Elective CABG & FC $(n=30) ;$ Placebo $(n=30)$ & Preoperative & $1 \mathrm{~g}$ & Less postoperative bleeding \\
\hline Jeppsson (2015) [129] & $\begin{array}{c}\text { Prospective, randomised, } \\
\text { double-blind }\end{array}$ & Elective low risk CABG & FC $(n=24) ;$ Placebo $(n=24)$ & $\begin{array}{c}\text { Preoperative if plasma } \\
\text { fibrinogen concentration } \leq \\
3.8 \mathrm{~g} / \mathrm{L}\end{array}$ & $2 \mathrm{~g}$ & $\begin{array}{l}\text { No significant difference in blood } \\
\text { loss, number of transfusions of } \\
\text { blood products, proportion of } \\
\text { transfused subjects; } \\
\text { Higher postoperative fibrinogen }\end{array}$ \\
\hline $\begin{array}{c}\text { Rahe-Meyer (2013) } \\
\text { [134] }\end{array}$ & $\begin{array}{c}\text { Prospective, randomised, } \\
\text { double-blind }\end{array}$ & $\begin{array}{l}\text { Elective thoracic or } \\
\text { thoracoabdominal aortic } \\
\text { replacement surgery }\end{array}$ & FC $(n=29) ;$ Placebo $(n=32)$ & $\begin{array}{l}\text { After removal from CPB } \\
\text { and surgical haemostasis } \\
\text { when } 5 \text { min bleeding mass } \\
\text { is } 60-250 \mathrm{~g}\end{array}$ & $\begin{array}{l}8 \mathrm{~g}(6-9) \mathrm{g} \text {; Target } \\
\text { FIBTEM MCF } 22 \mathrm{~mm}\end{array}$ & $\begin{array}{c}\text { Less transfusion of blood } \\
\text { products; Total avoidance of } \\
\text { transfusion; Higher fibrinogen at } \\
\text { the end of surgery }\end{array}$ \\
\hline $\begin{array}{l}\text { Rahe-Meyer } \\
\text { (2016) [131] (REPLACE } \\
\text { study) }\end{array}$ & $\begin{array}{l}\text { Multinational, multicentre, } \\
\text { prospective, randomised, } \\
\text { double-blind }\end{array}$ & Elective aortic surgery & FC $(n=7) ;$ Placebo $(n=74)$ & $\begin{array}{c}\text { After removal from CPB } \\
\text { and surgical haemostasis } \\
\text { when } 5 \text { min bleeding mass } \\
\text { is } 60-250 \mathrm{~g}\end{array}$ & $\begin{array}{l}8 \mathrm{~g}(6-9) \mathrm{g} \text {; Target } \\
\text { FIBTEM MCF } 22 \mathrm{~mm}\end{array}$ & $\begin{array}{l}\text { More blood product transfusion; } \\
\text { Fewer patients avoided } \\
\text { transfusion; Increased plasma } \\
\text { fibrinogen concentration and } \\
\text { fibrin-based clot strength }\end{array}$ \\
\hline $\begin{array}{l}\text { Ranucci (2015) [118] } \\
\text { (ZEPLAST study) }\end{array}$ & $\begin{array}{l}\text { Prospective, randomised, } \\
\text { double-blind }\end{array}$ & $\begin{array}{c}\text { Cardiac surgery with CPB > } \\
90 \text { min and one of: age }>65 \\
\text { years, non-elective surgery, } \\
\text { serum creatinine level }> \\
1.36 \mathrm{mg} / \mathrm{dl} \text {, redo surgery }\end{array}$ & FC $(n=58) ;$ Placebo $(n=58)$ & $\begin{array}{l}\text { After protamine } \\
\text { administration }\end{array}$ & $\begin{array}{l}4 \mathrm{~g}(3-6) \mathrm{g} \text {; Target } \\
\text { FIBTEM MCF } 22 \mathrm{~mm}\end{array}$ & $\begin{array}{c}\text { Lower rate of blood products } \\
\text { transfusion; Less postoperative } \\
\text { bleeding }\end{array}$ \\
\hline Bilecen (2017) [82] & $\begin{array}{l}\text { Prospective, randomised, } \\
\text { double-blind }\end{array}$ & $\begin{array}{l}\text { Elective high-risk cardiac } \\
\text { surgery }\end{array}$ & FC $(n=60) ;$ Placebo $(n=60)$ & $\begin{array}{l}\text { After CPB when } 5 \mathrm{~min} \\
\text { intraoperative blood } \\
\text { volume is } 60-250 \mathrm{ml}\end{array}$ & $\begin{array}{l}\text { Mean dose } 3.1 \mathrm{~g} / \mathrm{L} \text {; Target } \\
\text { Clauss fibrinogen } 2.5 \mathrm{~g} / \mathrm{L}\end{array}$ & $\begin{array}{l}\text { No difference in intraoperative } \\
\text { blood loss; No difference in blood } \\
\text { transfusions }\end{array}$ \\
\hline
\end{tabular}


Table 2. Cont.

\begin{tabular}{|c|c|c|c|c|c|c|}
\hline Author (Year) & Type of Study & Type of Surgery & Number of Patients & Timing of Intervention & $\begin{array}{c}\text { Dose of } \\
\text { Fibrinogen/Control } \\
\text { Drug } \pm \text { Target Dose }\end{array}$ & $\begin{array}{l}\text { Associated Outcome } \\
\text { (FC Group) }\end{array}$ \\
\hline Kwapisz (2020) [10] & $\begin{array}{l}\text { Prospective, randomised, } \\
\text { double-blind }\end{array}$ & $\begin{array}{l}\text { Elective high-risk cardiac } \\
\text { surgery and preoperative } \\
\text { fibrinogen } \leq 3.8 \mathrm{~g} / \mathrm{L}\end{array}$ & FC $(n=31) ;$ Placebo $(n=31)$ & After heparin reversal & $\begin{array}{l}\text { Mean dose } 3.2 \mathrm{~g} / \mathrm{L} \text {; Target } \\
\text { FIBTEM MCF } \geq 15 \mathrm{~mm}\end{array}$ & $\begin{array}{l}\text { Less cumulative blood product } \\
\text { units transfusion but not } \\
\text { statistically significant; No } \\
\text { difference in number of transfused } \\
\text { patients; A trend toward less } \\
\text { blood drainage; Higher FIBTEM } \\
\text { MCF; Higher fibrinogen plasma } \\
\text { levels at the end of surgery }\end{array}$ \\
\hline Bilecen (2013) [132] & $\begin{array}{l}\text { Prospective, } \\
\text { nonrandomised }\end{array}$ & Complex cardiac surgery & $\begin{array}{c}\text { FC }(n=264) ; \text { Conventional } \\
\text { therapy }(n=811)\end{array}$ & $\begin{array}{l}\text { During surgery, in case the } \\
\text { initial haemostatic } \\
\text { management was not } \\
\text { effective, and a surgical } \\
\text { source of bleeding was } \\
\text { excluded }\end{array}$ & $2 \mathrm{~g}(2$ to $3 \mathrm{~g})$ & $\begin{array}{l}\text { No difference in postoperative } \\
\text { blood loss and transfusion of } \\
\text { blood products }\end{array}$ \\
\hline Yang (2013) [112] & Retrospective, observational & Cardiac surgery procedures & $\begin{array}{c}\text { FC }(n=8) ; \text { Cryoprecipitate } \\
(n=76)\end{array}$ & $\begin{array}{l}\text { ICU within } 12 \mathrm{~h} \text { of } \\
\text { completion of surgery }\end{array}$ & $\begin{array}{c}\mathrm{FC} 46.28 \pm 33.64 \mathrm{mg} / \mathrm{kg} \\
\text { Cryoprecipitate } 4.76 \pm \\
2.94 \mathrm{~mL} / \mathrm{kg}\end{array}$ & $\begin{array}{l}\text { Not significantly reduced } \\
\text { bleeding rate after FC or } \\
\text { cryoprecipitate infusion }\end{array}$ \\
\hline Hanna 2016 [6] & Prospective, pilot, off-label & $\begin{array}{l}\text { High-risk proximal aortic } \\
\text { reconstruction with DHCA }\end{array}$ & $\begin{array}{c}\mathrm{FC}(n=22) ; \\
\text { Propensity-matched cohort } \\
(n=22)\end{array}$ & After separation from $\mathrm{CPB}$ & $70 \mathrm{mg} / \mathrm{kg}$ & $\begin{array}{l}\text { Rapidly raised fibrinogen levels; } \\
\text { Reduced transfusion requirement }\end{array}$ \\
\hline Lupu (2018) [135] & Retrospective & $\begin{array}{l}\text { Elective or emergency } \\
\text { cardiac surgery }\end{array}$ & $\begin{array}{c}\text { FC }(n=73) ; \\
\text { Propensity-matched cohort } \\
(n=73)\end{array}$ & $\begin{array}{c}\text { If bleeding persisted after } \\
\text { protamine administration } \\
\text { and FIBTEM MCF }<6 \mathrm{~mm} \text {, } \\
\text { not first-line therapy }\end{array}$ & $1 \mathrm{~g}$ & $\begin{array}{l}\text { Higher bleeding and more } \\
\text { transfusion of blood products }\end{array}$ \\
\hline Hakimi (2019) [91] & Prospective, observational & Cardiac surgery procedures & $\begin{array}{l}\text { FC }(n=16) ; \text { Platelet } \\
\text { concentrate }(n=12) ; \text { FC and } \\
\text { platelet concentrate }(n=14)\end{array}$ & $\begin{array}{c}\text { Ongoing bleeding after } \\
\text { surgery and FIBTEM MCF } \\
\leq 10 \mathrm{~mm}\end{array}$ & $\begin{array}{l}\text { FC 2 (1-3) g; Platelet } \\
\text { concentrate } 2 \text { (1-3) units; } \\
\text { FC 2 (1-4) g and platelet } \\
\text { concentrate } 2 \text { (1-3) units }\end{array}$ & $\begin{array}{l}\text { Higher FIBTEM MCF; Lower } \\
\text { bleeding volume after FC or FC } \\
\text { and platelet concentrate }\end{array}$ \\
\hline
\end{tabular}

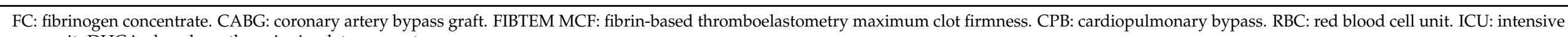
care unit. DHCA: deep hypothermic circulatory arrest. 
These studies did not support the prophylactic preoperative use of FC in patients at a low risk of bleeding and fibrinogen levels $<3.8 \mathrm{~g} / \mathrm{L}$, as suggested in previous ESA guidelines published in 2013 [136]. The updated guidelines do not contain this recommendation [73]. It remains to investigate the impact of preoperative FC administration on postoperative bleeding in patients with an increased risk of bleeding who undergo complex cardiac surgery and/or have lower preoperative fibrinogen concentrations.

A larger number of studies have investigated the use of FC immediately after $\mathrm{CPB}$ as a prophylactic approach or first-line therapy after a bleeding assessment.

A Cochrane review published in 2013 assessed the benefits and harm of FC treatment in a mixed population of bleeding patients [137]. The review included six RCTs, of which four included a population of cardiac surgery patients (Cui 2010, Galas 2012, Karlsson 2009, and Rahe-Meyer 2013); one included a mixed population of cardiac surgery and major abdominal and spinal surgery patients (Lance 2011); and one included a population of patients with urological cancer surgery (Fenger-Eriksen 2009a). The review did not show a significant effect on mortality but suggested a beneficial effect of FC in reducing the incidence of allogeneic blood transfusions.

This review included a RCT published the same year by Rahe-Meyer et al. [134]. This RCT was conducted on patients undergoing aortic replacement surgery. In the presence of clinically relevant coagulopathic bleeding after $\mathrm{CPB}$, patients received a FC or placebo. FC dosing was individualised using the FIBTEM test. The goal was FIBTEM MCF of $22 \mathrm{~mm}$. The rate of bleeding was quantified by measuring a 5 -min bleeding mass. This was defined as a bleeding mass of $60-250 \mathrm{~g}$, determined by weighing surgical sponges applied to the surgical area for $5 \mathrm{~min}$ immediately after removal from $\mathrm{CPB}$, neutralisation of heparin with protamine sulphate, and the completion of surgical haemostasis. The authors found that the transfusion of allogeneic blood components was significantly reduced in the FC group. Total avoidance of transfusion was achieved in $45 \%$ of the FC treated patients and in none of the patients in the control group.

With the same study design, a larger, multicentre, international RCT (REPLACE) was published 2016 [131]. This study provided contrary results to the previous study. FC use was associated with an increase in the administration of blood products. The authors admitted that it might be attributable to an overall low bleeding rate, the fact that many patients had plasma fibrinogen concentrations that would not trigger therapy in clinical practice (around $1.8 \mathrm{~g} / \mathrm{L}$ in both groups), and variability in adherence to the complex transfusion algorithm. The post hoc analysis of this study design revealed significant methodological challenges [138].

A Zero PLASma Trial: ZEPLAST was conducted simultaneously with REPLACE and published in 2015 [118]. ZEPLAST was a single-centre, prospective, randomised, placebocontrolled, double-blinded study on a selected patient population (expected CPB $>90 \mathrm{~min}$ and absence of anaemia, haemodilution, coagulopathy, and platelet dysfunction). Patients in the treatment group received FC after protamine administration as a measure to prevent bleeding. The dose was dependent on the FIBTEM MCF measured during CPB. The target FIBTEM MCF was $22 \mathrm{~mm}$. In this setting, the study demonstrated a significant reduction in postoperative bleeding and a significant reduction in allogeneic blood product transfusions in the FC-treated group and that FFP transfusions could be completely avoided using a strategy based on purified concentrates of coagulation factors. There was also a significant negative association between the fibrinogen values at arrival in the ICU and postoperative bleeding and between FIBTEM MCF and postoperative bleeding.

Again, a placebo-controlled RCT published in 2017 involved patients undergoing elective high-risk surgery without hypofibrinogenemia and with intraoperative coagulopathic bleeding according to the 5-min bleeding mass and volume [82]. When the test indicated intraoperative bleeding, patients were randomised to receive FC or placebo. FC doses were calculated based on the plasma fibrinogen levels measured with the Clauss method to achieve a fibrinogen level of $2.5 \mathrm{~g} / \mathrm{L}$. The primary outcome was blood loss between intervention and closure of the chest. The study did not show significant differences in the 
volume of blood loss between the FC and placebo groups. The authors explained it by the fact that the period between FC administration and the closure of the chest was relatively short. The total blood loss in $24 \mathrm{~h}$ was significantly lower in the FC group, although this difference was not clinically important. In addition, the authors observed more adverse events within 30 days in the FC group.

A recently published RCT in 2020 included patients undergoing elective high-risk cardiac surgery with preoperative fibrinogen levels $\leq 3.8 \mathrm{~g} / \mathrm{L}$ [10]. After weaning from CPB and the reversal of heparin, patients received FC or placebo. The FC dose was calculated according to the FIBTEM test to achieve at least a FIBTEM of $15 \mathrm{~mm}$ postoperatively. The study demonstrated that the early and prophylactic infusion of FC did not significantly reduce the blood product transfusion requirements, although it may have improved some coagulation parameters. The study was limited by a less-than-expected transfusion rate and the inability to reach the required sample size.

Bilecen et al. published in 2013 a prospective nonrandomised study conducted on high-risk cardiac surgery patients where 1 to $2 \mathrm{~g}$ of FC were administrated after CPB in case the initial haemostatic management was not effective [132]. The results were published in 2013 and showed that FC did not reduce the postoperative blood loss and transfusion requirements. The study was limited by significant differences between the two groups observed, the applied dose of FC, and the late application of FC.

In a retrospective study, Yang et al. compared blood loss before and after FC and cryoprecipitate infusion and found no statistically significant reduced bleeding rates [112].

Tanaka et al. conducted a small prospective, randomised, open-label, active drug control study [53]. After heparin reversal, they assessed the bleeding according to a visual scale. If moderate (controllable with applied pressure) or severe bleeding (multiple diffuse bleeding sites) bleeding was present, the patients were assigned to two groups. Patients in the first group received $4 \mathrm{~g}$ of FC and, in the second group, one unit of apheresis platelets. The interventions were followed by an institutional transfusion protocol. They found fewer platelet and cryoprecipitate transfusions and higher FIBTEM MCF in patients infused with FC.

Hanna et al., in a prospective pilot study, investigated FC utilisation in high-risk aortic reconstruction surgery with deep hypothermic circulatory arrest (DHCA). They compared patients receiving 70-mg $/ \mathrm{kg}$ FC upon separation from CPB with a contemporary propensity-matched cohort and found that FC may potentially reduce the transfusion requirements [6].

Lupu et al. published the results of a retrospective study in 2018, which showed that, in high-risk surgical patients with postoperative bleeding and FIBTEM MCF $<6 \mathrm{~mm}$, the administration of a low dose of FC of $1 \mathrm{~g}$ was not sufficient to stop the bleeding and reduce the need for blood transfusion [135]. FC was administered if the bleeding did not stop after treatment with FFP and a platelet concentrate and not as the first-line therapy. Patients receiving FC had a higher risk of bleeding than patients in the matching group, preoperatively lower fibrinogen levels and platelet counts, impaired other coagulation tests, and longer CPB time. All of these factors could affect the results. Future studies should investigate the effectiveness of a higher dose of FC at a higher trigger value and with earlier administration.

Hakimi et al. published, in 2019, an observational study investigating the effect of FC and/or platelet concentrate transfusion on the ROTEM coagulation parameters and postoperative blood loss in patients with ongoing bleeding after cardiac surgery [91]. In patients with significant bleeding, FC was administered if FIBTEM MCF was $\leq 10 \mathrm{~mm}$, and a platelet concentrate was administered if the platelet count was $<100 \times 10^{9} / \mathrm{L}$ and /or platelet dysfunction was suspected. Following FC administration, significantly increased FIBTEM MCF that correlated with an increase in the plasma fibrinogen concentration was found. When both platelets and FC were administered, improved clotting time, clot firmness, and platelet aggregation were found. Platelet transfusion improved platelet aggregation. In all three cases, a decrease in bleeding volume was observed. 
The presented studies differed in design and size; population included; FC dose administered; comparisons used; and the timing of the intervention (preoperative, postoperative, as prophylaxis, or therapy). The results were inconsistent, but they suggested that FC administration enhances haemostasis in patients with ongoing bleeding, as evident by the FIBTEM test, and may reduce the amount of postoperative bleeding. This was also shown in a recent review [139]. In addition, it has been shown that targeted fibrinogen supplementation according to a strict algorithm can not only reduce bleeding but completely suppress the use of blood products. It is currently unclear which patients and in which specific clinical scenario should receive fibrinogen concentrates, nor which is the best timing for administration. Since fibrinogen recovers rapidly after surgery in nonbleeding patients, the appropriateness of FC prophylactic use is questionable. Studies suggest that it is more reasonable to administer FC in a bleeding patient with proven hypofibrinogenemia [4,91].

According to the ESA guidelines, the treatment of hypofibrinogenemia in a bleeding patients is recommended [73]. The existing European Association for Cardiothoracic Surgery (EACTS) -European Association of Cardiothoracic Anaesthesiology (EACTA) guidelines do not recommend prophylactic fibrinogen administration for reducing postoperative bleeding and transfusion risks [50]. According to the guidelines, in patients with a low-fibrinogen level and signs of bleeding, fibrinogen substitution may be considered to reduce the requirement for transfusions.

\subsubsection{Trigger, Target Values, and Dosage}

The existing guidelines recommend, in the case of bleeding, individualised haemostatic therapy based on intervention algorithms with predefined triggers and targets based on point-of-care and/or standard coagulation tests [50,73].

Trigger values for fibrinogen supplementation in the case of post-CPB coagulopathic bleeding are fibrinogen concentrations of less than $1.5-2 \mathrm{~g} / \mathrm{L}$ according to the ESA guidelines [73] and $<1.5 \mathrm{~g} / \mathrm{L}$ or low clot firmness according to the EACTS/EACTA guidelines [50]. A fibrinogen concentration of $1.5 \mathrm{~g} / \mathrm{L}$ measured with the Clauss method should correspond to a FIBTEM MCF of 6-8 mm [90]. Based on the analysis of the ROC curve, Mace et al. determined that the optimal FIBTEM A10 cut-off for $8 \mathrm{~mm}$ had the best balance of sensitivity and specificity for predicting fibrinogen concentrations $<1.5 \mathrm{~g} / \mathrm{L}$ (PPV $42 \%$ and NPV 98\%) [86]. In the aforementioned studies, fibrinogen levels $<1.5 \mathrm{~g} / \mathrm{L}$ and $/$ or FIBTEM A10 $<6 \mathrm{~mm}$ [113] and fibrinogen levels $<2.2 \mathrm{~g} / \mathrm{L}[79,115]$ were associated with higher postoperative bleeding and $<2.0 \mathrm{~g} / \mathrm{L}$ with increased transfusion volumes [114]. Ranucci et al. identified that a 50\% PPV for severe bleeding corresponded to a fibrinogen level of $1.15 \mathrm{~g} / \mathrm{L}$ as a chest drain blood loss greater than $1000 \mathrm{~mL} / 12 \mathrm{~h}$ or the need for surgical re-exploration [115].

Studies that addressed fibrinogen target values demonstrated that an FIBTEM MCF $\geq 14 \mathrm{~mm}$ and a fibrinogen concentration $\geq 2.9 \mathrm{~g} / \mathrm{L}$ have a NPV of $99 \%$ to $100 \%$ for severe bleeding [90]. Ranucci et al., in a retrospective study, confirmed that fibrinogen levels $\geq 2.8 \mathrm{~g} / \mathrm{L}$ had a $98 \% \mathrm{NPV}$ for severe bleeding [115]. It is therefore to be assumed that dosing directed at these values may be sufficient to maintain haemostasis and to prevent excessive FC administration.

To control bleeding in complex cardiovascular surgery intraoperatively, the ESA guidelines suggest an initial FC dose of $25-50 \mathrm{mg} / \mathrm{kg}$ and, if FC is not available, cryoprecipitate at an initial dose of $4-6 \mathrm{~mL} / \mathrm{kg}$ [73]. Further, fibrinogen infusion guided by coagulation monitoring is recommended.

Target fibrinogen doses can be calculated according to the equations [15]. If the Clauss method is used, then the usual equation is:

Fibrinogen dose $(\mathrm{g})=($ target fibrinogen concentration $(\mathrm{g} / \mathrm{L})-$ actual fibrinogen concentration $(\mathrm{g} / \mathrm{L})) \times 0.07 \times(1$ - haematocrit $) \times$ body weight $(\mathrm{kg})$ 
The equation for FIBTEM is:

Fibrinogen dose $(\mathrm{g})=($ target FIBTEM MCF $(\mathrm{mm})-$ actual FIBTEM MCF $(\mathrm{mm}) \times$ body weight $(\mathrm{kg})) / 140$.

In a complex clinical scenario, when fibrinogen is continuously lost and there are deficits of the other coagulation factors and platelets, the trigger and target values may be higher. For example, Ranucci et al., in a retrospective study, found that thrombocytopenic patients after cardiac surgery with similar platelet counts and different levels of fibrinogen had different postoperative blood loss values and the need for FFP and platelet concentrate transfusions [140]. In this study, patients with higher fibrinogen levels showed less bleeding and the need for transfusions and significantly greater clot firmness than those with lower fibrinogen levels. The authors concluded that the endogenous levels of fibrinogen were able to compensate for the effects of thrombocytopenia by increasing and even normalising the clot firmness. They raised the hypothesis that fibrinogen supplementation in bleeding patients with thrombocytopenia may be a possible option to contain bleeding and avoid platelet concentrate transfusion.

Given the multiple aetiology of bleeding during cardiac surgery, fibrinogen management is only one part in maintaining haemostasis. In the management of postoperative bleeding, the combined effects of different procedures summarised in diagnostic and therapeutic algorithms are more effective than isolated interventions [141-146].

\section{Conclusions}

Fibrinogen is a key molecule for clot formation and haemostasis. Multiple factors in cardiac surgery lead to its rapid loss, which can be the cause of bleeding. Interventions aimed at reducing coagulation activation and minimising haemodilution and bleeding may be beneficial in reducing fibrinogen loss. The early diagnosis of fibrinogen disorder in bleeding patients and timely and targeted fibrinogen supplementation are required to maintain haemostasis. Viscoelastic tests enable the early diagnosis of hypofibrinogenemia and targeted therapy in cardiac surgery. Fibrinogen concentrate has multiple advantages over fresh-frozen plasma and cryoprecipitate, and its use can reduce postoperative bleeding. Further studies are needed to better understand the association between fibrinogen levels, bleeding, and fibrinogen supplementation and their impacts on patient outcomes in different clinical settings. The utmost research should establish an optimal therapy that can potentially reduce blood loss, the transfusion of blood products, and related patient outcomes.

Funding: This research received no external funding.

Institutional Review Board Statement: Not applicable.

Informed Consent Statement: Not applicable.

Data Availability Statement: Not applicable.

Conflicts of Interest: The author declares no conflict of interest.
Abbreviations
A5 amplitude at $5 \mathrm{~min}$
A10 amplitude at $10 \mathrm{~min}$
A20 amplitude at $20 \mathrm{~min}$
CABG coronary artery bypass graft 


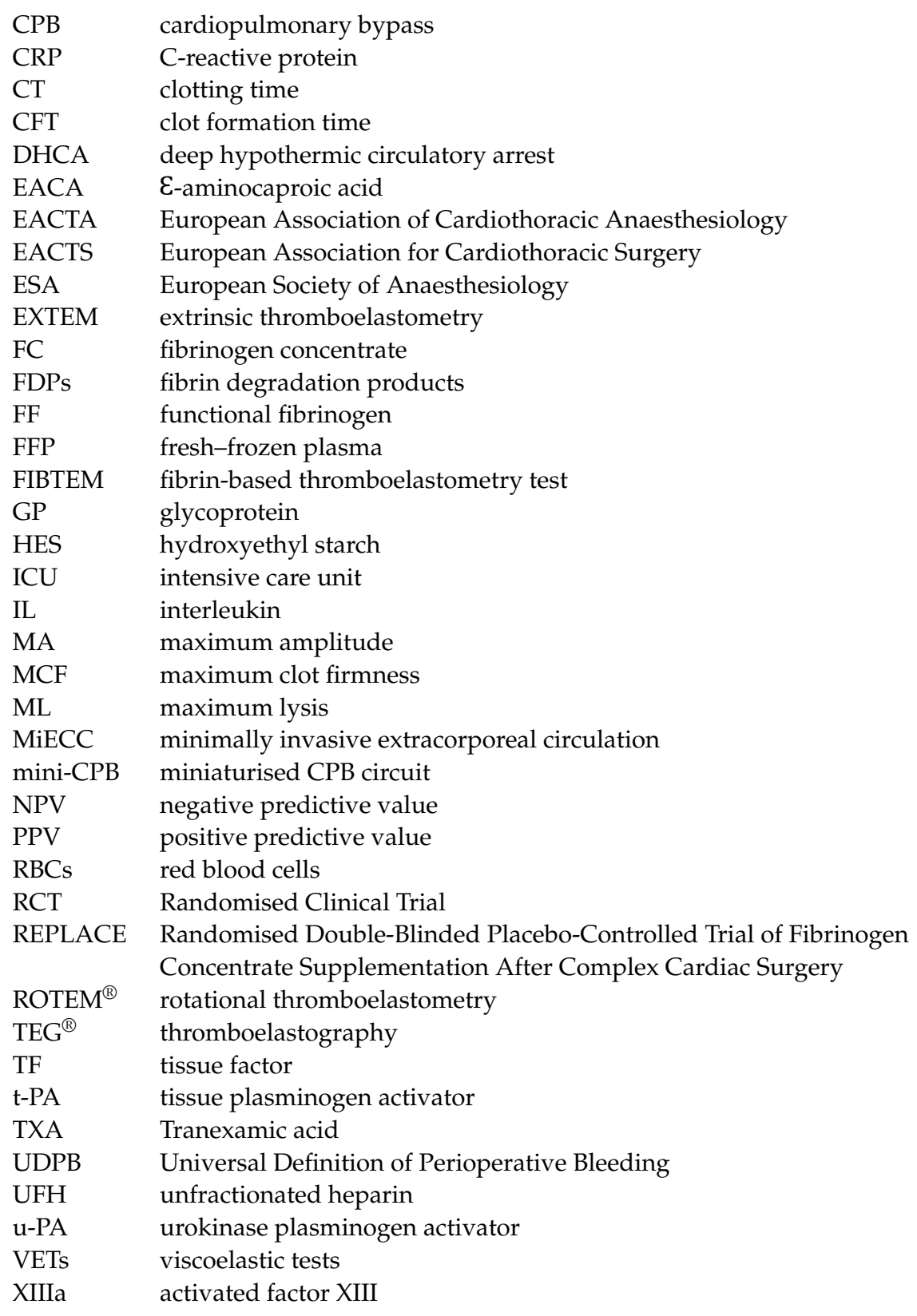

\section{References}

1. Sucker, C.; Zotz, R.B. The Cell-Based Coagulation Model. In Perioperative Hemostasis: Coagulation for Anesthesiologists; Marcucci, C.E., Schoettker, P., Eds.; Springer: Berlin/Heidelberg, Germany, 2015; pp. 3-11. ISBN 978-3-642-55004-1.

2. Kattula, S.; Byrnes, J.R.; Wolberg, A.S. Fibrinogen and Fibrin in Hemostasis and Thrombosis. ATVB 2017, 37. [CrossRef] [PubMed]

3. Momeni, M.; Carlier, C.; Baele, P.; Watremez, C.; Van Dyck, M.; Matta, A.; Kahn, D.; Rennotte, M.-T.; Glineur, D.; de Kerchove, L.; et al. Fibrinogen Concentration Significantly Decreases After On-Pump Versus Off-Pump Coronary Artery Bypass Surgery: A Systematic Point-of-Care ROTEM Analysis. J. Cardiothorac. Vasc. Anesth. 2013, 27, 5-11. [CrossRef]

4. $\quad$ Erdoes, G.; Dietrich, W.; Stucki, M.P.; Merz, T.M.; Angelillo-Scherrer, A.; Nagler, M.; Carrel, T.; Eberle, B. Short-Term Recovery Pattern of Plasma Fibrinogen after Cardiac Surgery: A Prospective Observational Study. PLoS ONE 2018, 13, e0201647. [CrossRef]

5. Roy, S.; Saha, K.; Mukherjee, K.; Dutta, S.; Mukhopadhyay, D.; Das, I.; Raychaudhuri, G. Activation of Coagulation and Fibrinolysis During Coronary Artery Bypass Grafting: A Comparison Between On-Pump and Off-Pump Techniques. Indian J. Hematol. Blood Transfus. 2014, 30, 333-341. [CrossRef] [PubMed]

6. Hanna, J.M.; Keenan, J.E.; Wang, H.; Andersen, N.D.; Gaca, J.G.; Lombard, F.W.; Welsby, I.J.; Hughes, G.C. Use of Human Fibrinogen Concentrate during Proximal Aortic Reconstruction with Deep Hypothermic Circulatory Arrest. J. Thorac. Cardiovasc. Surg. 2016, 151, 376-382. [CrossRef] [PubMed] 
7. $\quad$ Raspé, C.; Besch, M.; Charitos, E.I.; Flöther, L.; Bucher, M.; Rückert, F.; Treede, H. Rotational Thromboelastometry for Assessing Bleeding Complications and Factor XIII Deficiency in Cardiac Surgery Patients. Clin. Appl. Thromb. Hemost. 2018, 24, 136S-144S. [CrossRef]

8. Sniecinski, R.M.; Chandler, W.L. Activation of the Hemostatic System During Cardiopulmonary Bypass. Anesth. Analg. 2011, 113, 1319-1333. [CrossRef] [PubMed]

9. Pillai, R.C.; Fraser, J.F.; Ziegenfuss, M.; Bhaskar, B. The Influence of Circulating Levels of Fibrinogen and Perioperative Coagulation Parameters on Predicting Postoperative Blood Loss in Cardiac Surgery: A Prospective Observational Study: Role of Fibrinogen in Perioperative Bleeding, a Prospective Observational Study. J. Card. Surg. 2014, 29, 189-195. [CrossRef]

10. Kwapisz, M.M.; Kent, B.; DiQuinzio, C.; LeGare, J.; Garnett, S.; Swyer, W.; Whynot, S.; Mingo, H.; Scheffler, M. The Prophylactic Use of Fibrinogen Concentrate in High-risk Cardiac Surgery. Acta Anaesthesiol. Scand. 2020, 64, 602-612. [CrossRef] [PubMed]

11. Nishi, T.; Mutsuga, M.; Akita, T.; Narita, Y.; Fujimoto, K.; Tokuda, Y.; Terazawa, S.; Ito, H.; Nishiwaki, K.; Usui, A. The Incidence and Risk Factors of Hypofibrinogenemia in Cardiovascular Surgery. Gen. Thorac. Cardiovasc. Surg. 2020, 68, 335-341. [CrossRef]

12. Tanaka, K.A.; Esper, S.; Bolliger, D. Perioperative Factor Concentrate Therapy. Br. J. Anaesth. 2013, 111, i35-i49. [CrossRef] [PubMed]

13. Ranucci, M. Hemostatic and Thrombotic Issues in Cardiac Surgery. Semin. Thromb. Hemost. 2015, 41, 084-090. [CrossRef] [PubMed]

14. Gielen, C.L.I.; Grimbergen, J.; Klautz, R.J.M.; Koopman, J.; Quax, P.H.A. Fibrinogen Reduction and Coagulation in Cardiac Surgery: An Investigational Study. Blood Coagul. Fibrinolysis 2015, 26, 613-620. [CrossRef]

15. Levy, J.H.; Welsby, I.; Goodnough, L.T. Fibrinogen as a Therapeutic Target for Bleeding: A Review of Critical Levels and Replacement Therapy: Fibrinogen: A Therapeutic Target for Bleeding. Transfusion 2014, 54, 1389-1405. [CrossRef] [PubMed]

16. Perelman, I.; Saidenberg, E.; Tinmouth, A.; Fergusson, D. Trends and Outcomes in Multicomponent Blood Transfusion: An 11-year Cohort Study of a Large Multisite Academic Center. Transfusion 2019, 59, 1971-1987. [CrossRef] [PubMed]

17. Dyke, C.; Aronson, S.; Dietrich, W.; Hofmann, A.; Karkouti, K.; Levi, M.; Murphy, G.J.; Sellke, F.W.; Shore-Lesserson, L.; von Heymann, C.; et al. Universal Definition of Perioperative Bleeding in Adult Cardiac Surgery. J. Thorac. Cardiovasc. Surg. 2014, 147, 1458-1463.e1. [CrossRef]

18. Greiff, G.; Pleym, H.; Stenseth, R.; Berg, K.S.; Wahba, A.; Videm, V. Prediction of Bleeding After Cardiac Surgery: Comparison of Model Performances: A Prospective Observational Study. J. Cardiothorac. Vasc. Anesth. 2015, 29, 311-319. [CrossRef] [PubMed]

19. Bartoszko, J.; Wijeysundera, D.N.; Karkouti, K.; on behalf of the Transfusion Avoidance in Cardiac Surgery Study Investigators; Callum, J.; Rao, V.; Crowther, M.; Grocott, H.P.; Pinto, R.; Scales, D.C.; et al. Comparison of Two Major Perioperative Bleeding Scores for Cardiac Surgery Trials. Anesthesiology 2018, 129, 1092-1100. [CrossRef]

20. Ternström, L.; Hyllner, M.; Backlund, E.; Schersten, H.; Jeppsson, A. A Structured Blood Conservation Programme Reduces Transfusions and Costs in Cardiac Surgery. Interact. Cardiovasc. Thorac. Surg. 2014, 19, 788-794. [CrossRef]

21. Mazer, C.D.; Whitlock, R.P.; Fergusson, D.A.; Belley-Cote, E.; Connolly, K.; Khanykin, B.; Gregory, A.J.; de Médicis, É.; Carrier, F.M.; McGuinness, S.; et al. Six-Month Outcomes after Restrictive or Liberal Transfusion for Cardiac Surgery. N. Engl. J. Med. 2018, 379, 1224-1233. [CrossRef] [PubMed]

22. Stone, G.W.; Clayton, T.C.; Mehran, R.; Dangas, G.; Parise, H.; Fahy, M.; Pocock, S.J. Impact of Major Bleeding and Blood Transfusions after Cardiac Surgery: Analysis from the Acute Catheterization and Urgent Intervention Triage StrategY (ACUITY) Trial. Am. Heart J. 2012, 163, 522-529. [CrossRef] [PubMed]

23. Biancari, F.; Mikkola, R.; Heikkinen, J.; Lahtinen, J.; Airaksinen, K.E.J.; Juvonen, T. Estimating the Risk of Complications Related to Re-Exploration for Bleeding after Adult Cardiac Surgery: A Systematic Review and Meta-Analysis. Eur. J. Cardio-Thorac. Surg. 2011, 41, 50-55. [CrossRef] [PubMed]

24. Canadyova, J.; Zmeko, D.; Mokracek, A. Re-Exploration for Bleeding or Tamponade after Cardiac Operation. Interact. Cardiovasc. Thorac. Surg. 2012, 14, 704-707. [CrossRef] [PubMed]

25. Fröjd, V.; Jeppsson, A. Reexploration for Bleeding and Its Association With Mortality After Cardiac Surgery. Ann. Thorac. Surg. 2016, 102, 109-117. [CrossRef] [PubMed]

26. Vivacqua, A.; Koch, C.G.; Yousuf, A.M.; Nowicki, E.R.; Houghtaling, P.L.; Blackstone, E.H.; Sabik, J.F. Morbidity of Bleeding After Cardiac Surgery: Is It Blood Transfusion, Reoperation for Bleeding, or Both? Ann. Thorac. Surg. 2011, 91, 1780-1790. [CrossRef]

27. Essa, Y.; Zeynalov, N.; Sandhaus, T.; Hofmann, M.; Lehmann, T.; Doenst, T. Low Fibrinogen Is Associated with Increased Bleeding-Related Re-Exploration after Cardiac Surgery. Thorac. Cardiovasc. Surg. 2018, 66, 622-628. [CrossRef] [PubMed]

28. Ranucci, M.; Baryshnikova, E.; Castelvecchio, S.; Pelissero, G. Major Bleeding, Transfusions, and Anemia: The Deadly Triad of Cardiac Surgery. Ann. Thorac. Surg. 2013, 96, 478-485. [CrossRef] [PubMed]

29. Göbel, K.; Eichler, S.; Wiendl, H.; Chavakis, T.; Kleinschnitz, C.; Meuth, S.G. The Coagulation Factors Fibrinogen, Thrombin, and Factor XII in Inflammatory Disorders-A Systematic Review. Front. Immunol. 2018, 9, 1731. [CrossRef]

30. Fish, R.J.; Neerman-Arbez, M. Fibrinogen Gene Regulation. Thromb. Haemost. 2012, 108, 419-426. [CrossRef]

31. Tabakc1, M.M.; Gerin, F.; Sunbul, M.; Toprak, C.; Durmuş, H.İ.; Demir, S.; Arslantaş, U.; Cerşit, S.; Batgerel, U.; Kargın, R. Relation of Plasma Fibrinogen Level With the Presence, Severity, and Complexity of Coronary Artery Disease. Clin. Appl. Thromb. Hemost. 2017, 23, 638-644. [CrossRef]

32. Hong, L.-F.; Li, X.-L.; Luo, S.-H.; Guo, Y.-L.; Zhu, C.-G.; Qing, P.; Wu, N.-Q.; Li, J.-J. Association of Fibrinogen with Severity of Stable Coronary Artery Disease in Patients with Type 2 Diabetic Mellitus. Dis. Markers 2014, 2014, 485687. [CrossRef] [PubMed] 
33. Song, J.; Yu, T.; Sun, Z.; Li, Z.; He, D.; Sun, Z. Comparison of Prognostic Significance between Serum Fibrinogen and Global Registry of Acute Coronary Events Score for Prognosis of Patients with Non-ST-Elevation Acute Coronary Syndromes Undergoing Percutaneous Coronary Intervention. Coron. Artery Dis. 2020, 31, 124-129. [CrossRef] [PubMed]

34. Roberts, H.; Hoffman, M.; Monroe, D. A Cell-Based Model of Thrombin Generation. Semin. Thromb. Hemost. 2006, 32, 32-38. [CrossRef]

35. Weisel, J.W.; Litvinov, R.I. Fibrin Formation, Structure and Properties. In Fibrous Proteins: Structures and Mechanisms; Parry, D.A.D., Squire, J.M., Eds.; Springer International Publishing: Cham, Switzerland, 2017; Volume 82, pp. 405-456. ISBN 978-3-319-49672-6.

36. McMichael, M. New Models of Hemostasis. Top. Companion Anim. Med. 2012, 27, 40-45. [CrossRef] [PubMed]

37. Urano, T.; Suzuki, Y.; Iwaki, T.; Sano, H.; Honkura, N.; Castellino, F.J. Recognition of Plasminogen Activator Inhibitor Type 1 as the Primary Regulator of Fibrinolysis. Curr. Drug Targets 2019, 20, 1695-1701. [CrossRef] [PubMed]

38. Longstaff, C.; Kolev, K. Basic Mechanisms and Regulation of Fibrinolysis. J. Thromb. Haemost. 2015, 13, S98-S105. [CrossRef]

39. Hoppe, B. Fibrinogen and Factor XIII at the Intersection of Coagulation, Fibrinolysis and Inflammation. Thromb. Haemost. 2014, 112, 649-658. [CrossRef] [PubMed]

40. Gielen, C.L.I.; Brand, A.; van Heerde, W.L.; Stijnen, T.; Klautz, R.J.M.; Eikenboom, J. Hemostatic Alterations during Coronary Artery Bypass Grafting. Thromb. Res. 2016, 140, 140-146. [CrossRef] [PubMed]

41. Esper, S.A.; Subramaniam, K.; Tanaka, K.A. Pathophysiology of Cardiopulmonary Bypass: Current Strategies for the Prevention and Treatment of Anemia, Coagulopathy, and Organ Dysfunction. Semin. Cardiothorac. Vasc. Anesth. 2014, 18, 161-176. [CrossRef] [PubMed]

42. Bethlehem, I.; Wierda, K.; Visser, C.; Jekel, L.; Koopmans, M.; Kuiper, M.A. Influence of Two Colloidal Extracorporeal Primes on Coagulation of Cardiac Surgical Patients: A Prospectively Randomized Open-Label Pilot Trial. J. Extra Corpor. Technol. 2014, 46, 293-299.

43. Van der Linden, P.; Ickx, B.E. The Effects of Colloid Solutions on Hemostasis. Can. J. Anesth. 2006, 53, S30-S39. [CrossRef]

44. Jin, S.; Yu, B. Effects of Artificial Colloids on Haemostasis. Br. J. Hosp. Med. 2009, 70, 101-103. [CrossRef] [PubMed]

45. Stump, D.C.; Strauss, R.G.; Henriksen, R.A.; Petersen, R.E.; Saunders, R. Effects of Hydroxyethyl Starch on Blood Coagulation, Particularly Factor VIII. Transfusion 1985, 25, 349-354. [CrossRef] [PubMed]

46. Treib, J.; Haass, A.; Pindur, G. Coagulation Disorders Caused by Hydroxyethyl Starch. Thromb. Haemost. 1997, 78, 974-983. [CrossRef] [PubMed]

47. Nielsen, V.G. Colloids Decrease Clot Propagation and Strength: Role of Factor XIII-Fibrin Polymer and Thrombin-Fibrinogen Interactions. Acta Anaesthesiol. Scand. 2005, 49, 1163-1171. [CrossRef] [PubMed]

48. Schramko, A.; Suojaranta-Ylinen, R.; Kuitunen, A.; Raivio, P.; Kukkonen, S.; Niemi, T. Hydroxyethylstarch and Gelatin Solutions Impair Blood Coagulation after Cardiac Surgery: A Prospective Randomized Trial. Br. J. Anaesth. 2010, 104, 691-697. [CrossRef]

49. Ghijselings, I.; Himpe, D.; Rex, S. Safety of Gelatin Solutions for the Priming of Cardiopulmonary Bypass in Cardiac Surgery: A Systematic Review and Meta-Analysis. Perfusion 2017, 32, 350-362. [CrossRef]

50. Pagano, D.; Milojevic, M.; Meesters, M.I.; Benedetto, U.; Bolliger, D.; von Heymann, C.; Jeppsson, A.; Koster, A.; Osnabrugge, R.L.; Ranucci, M.; et al. 2017 EACTS/EACTA Guidelines on Patient Blood Management for Adult Cardiac Surgery. Eur. J. Cardio-Thorac. Surg. 2018, 53, 79-111. [CrossRef]

51. Raphael, J.; Mazer, C.D.; Subramani, S.; Schroeder, A.; Abdalla, M.; Ferreira, R.; Roman, P.E.; Patel, N.; Welsby, I.; Greilich, P.E.; et al. Society of Cardiovascular Anesthesiologists Clinical Practice Improvement Advisory for Management of Perioperative Bleeding and Hemostasis in Cardiac Surgery Patients. J. Cardiothorac. Vasc. Anesth. 2019, 33, 2887-2899. [CrossRef]

52. Smith, B.B.; Nuttall, G.A.; Mauermann, W.J.; Schroeder, D.R.; Scott, P.D.; Smith, M.M. Coagulation Test Changes Associated with Acute Normovolemic Hemodilution in Cardiac Surgery. J. Card. Surg. 2020, 35, 1043-1050. [CrossRef]

53. Tanaka, K.A.; Egan, K.; Szlam, F.; Ogawa, S.; Roback, J.D.; Sreeram, G.; Guyton, R.A.; Chen, E.P. Transfusion and Hematologic Variables after Fibrinogen or Platelet Transfusion in Valve Replacement Surgery: Preliminary Data of Purified Lyophilized Human Fibrinogen Concentrate versus Conventional Transfusion: Fibrinogen versus PLT Concentrate in Valve Replacement. Transfusion 2014, 54, 109-118. [CrossRef] [PubMed]

54. Sato, H.; Yamamoto, K.; Kakinuma, A.; Nakata, Y.; Sawamura, S. Accelerated Activation of the Coagulation Pathway during Cardiopulmonary Bypass in Aortic Replacement Surgery: A Prospective Observational Study. J. Cardiothorac. Surg. 2015, 10, 84. [CrossRef] [PubMed]

55. Morisaki, A.; Nakahira, A.; Sasaki, Y.; Hirai, H.; Okada, Y.; Suehiro, S.; Shibata, T. Is Elimination of Cardiotomy Suction Preferable in Aortic Valve Replacement? Assessment of Perioperative Coagulation, Fibrinolysis and Inflammation. Interact. Cardiovasc. Thorac. Surg. 2013, 17, 507-514. [CrossRef] [PubMed]

56. Giri, H.; Panicker, S.R.; Cai, X.; Biswas, I.; Weiler, H.; Rezaie, A.R. Thrombomodulin Is Essential for Maintaining Quiescence in Vascular Endothelial Cells. Proc. Natl. Acad. Sci. USA 2021, 118, e2022248118. [CrossRef]

57. Esmon, C.T. The Normal Role of Activated Protein C in Maintaining Homeostasis and Its Relevance to Critical Illness. Crit. Care 2001, 5, S7. [CrossRef]

58. Gorki, H.; Nakamura, J.; Kunert, A.; Hoenicka, M.; Liebold, A. Pericardial Fluids or Cardiopulmonary Bypass-Is There a Major Culprit for Changes in Coagulation and Inflammation? Thorac. Cardiovasc. Surg. 2020, 68, 219-222. [CrossRef]

59. Gäbel, J.; Hakimi, C.S.; Westerberg, M.; Radulovic, V.; Jeppsson, A. Retransfusion of Cardiotomy Suction Blood Impairs Haemostasis: Ex Vivo and in Vivo Studies. Scand. Cardiovasc. J. 2013, 47, 368-376. [CrossRef] 
60. Paparella, D.; Whitlock, R. Safety of Salvaged Blood and Risk of Coagulopathy in Cardiac Surgery. Semin. Thromb. Hemost. 2016, 42, 166-171. [CrossRef]

61. Adam, E.H.; Funke, M.; Zacharowski, K.; Meybohm, P.; Keller, H.; Weber, C.F. Impact of Intraoperative Cell Salvage on Blood Coagulation Factor Concentrations in Patients Undergoing Cardiac Surgery. Anesth. Analg. 2020, 130, 1389-1395. [CrossRef]

62. Sharma, A.D.; Al-Achi, A.; Seccombe, J.F.; Hummel, R.; Preston, M.; Behrend, D. Does Incorporation of Thromboelastography Improve Bleeding Prediction Following Adult Cardiac Surgery? Blood Coagul. Fibrinolysis 2014, 25, 561-570. [CrossRef]

63. Boyle, G.; Kuffel, A.; Parmar, K.; Gibson, K.; Smith, M.; Grehan, A.; Hunt, B.J.; Chambers, D.J. A Comparison of Haemostatic Biomarkers during Low-Risk Patients Undergoing Cardiopulmonary Bypass Using Either Conventional Centrifugal Cell Salvage or the HemoSep Device. Perfusion 2019, 34, 76-83. [CrossRef] [PubMed]

64. McNair, E.; McKay, W.; Qureshi, A.M.; Rosin, M.; Gamble, J.; Dalshaug, G.; Mycyk, T.; Prasad, K. Outcomes and Biochemical Parameters Following Cardiac Surgery: Effects of Transfusion of Residual Blood Using Centrifugation and Multiple-Pass Hemoconcentration. J. Cardiothorac. Vasc. Anesth. 2013, 27, 1174-1180. [CrossRef]

65. Colli, A.; Balduzzi, S.; Ruyra, X. The Hemobag: The Modern Ultrafiltration System for Patients Undergoing Cardiopulmonary by Pass. J. Cardiothorac. Surg. 2012, 7, 55. [CrossRef]

66. Beckmann, S.; Lynn, P.; Miller, S.; Harris, R.; DiMarco, R.; Ross, J. Evaluation of Coagulation Factors and Platelet Function from an Off-Line Modified Ultrafiltration Technique for Post-Cardiopulmonary Bypass Circuit Blood Recovery. Perfusion 2013, 28, 214-222. [CrossRef] [PubMed]

67. Paparella, D.; Parolari, A.; Rotunno, C.; Vincent, J.; Myasoedova, V.; Guida, P.; De Palo, M.; Margari, V.; Devereaux, P.J.; Lamy, A.; et al. The Effects of Steroids on Coagulation Dysfunction Induced by Cardiopulmonary Bypass: A Steroids in Cardiac Surgery (SIRS) Trial Substudy. Semin. Thorac. Cardiovasc. Surg. 2017, 29, 35-44. [CrossRef] [PubMed]

68. Onorati, F.; Santini, F.; Raffin, F.; Menon, T.; Graziani, M.S.; Chiominto, B.; Milano, A.; Faggian, G.; Mazzucco, A. Clinical Evaluation of New Generation Oxygenators With Integrated Arterial Line Filters for Cardiopulmonary Bypass: Clinical Outcome with New Integrated Filter Oxygenators. Artif. Organs 2012, 36, 875-885. [CrossRef]

69. Fluger, I.; Maderová, K.; Šimek, M.; Hájek, R.; Zapletalová, J.; Lonský, V. The Effect of a Cardiopulmonary Bypass System with Biocompatible Coating on Fibrinogen Levels Determined by the TEG-Functional Fibrinogen Method: Preliminary Results. Perfusion 2011, 26, 503-509. [CrossRef]

70. Zindovic, I.; Sjögren, J.; Bjursten, H.; Ingemansson, R.; Ingimarsson, J.; Larsson, M.; Svensson, P.J.; Strandberg, K.; Wierup, P.; Nozohoor, S. The Coagulopathy of Acute Type A Aortic Dissection: A Prospective, Observational Study. J. Cardiothorac. Vasc. Anesth. 2019, 33, 2746-2754. [CrossRef] [PubMed]

71. Liu, Y.; Han, L.; Li, J.; Gong, M.; Zhang, H.; Guan, X. Consumption Coagulopathy in Acute Aortic Dissection: Principles of Management. J. Cardiothorac. Surg. 2017, 12, 50. [CrossRef]

72. Guan, X.L.; Wang, X.L.; Liu, Y.Y.; Lan, F.; Gong, M.; Li, H.Y.; Liu, O.; Jiang, W.J.; Liu, Y.M.; Zhu, J.M.; et al. Changes in the Hemostatic System of Patients With Acute Aortic Dissection Undergoing Aortic Arch Surgery. Ann. Thorac. Surg. 2016, 101, 945-951. [CrossRef] [PubMed]

73. Kozek-Langenecker, S.A.; Ahmed, A.B.; Afshari, A.; Albaladejo, P.; Aldecoa, C.; Barauskas, G.; De Robertis, E.; Faraoni, D.; Filipescu, D.C.; Fries, D.; et al. Management of Severe Perioperative Bleeding: Guidelines from the European Society of Anaesthesiology: First Update 2016. Eur. J. Anaesthesiol. EJA 2017, 34, 332-395. [CrossRef] [PubMed]

74. Wu, Y. Contact Pathway of Coagulation and Inflammation. Thromb. J. 2015, 13, 17. [CrossRef] [PubMed]

75. Brown, N.J.; Gainer, J.V.; Murphey, L.J.; Vaughan, D.E. Bradykinin Stimulates Tissue Plasminogen Activator Release From Human Forearm Vasculature Through B2 Receptor-Dependent, NO Synthase-Independent, and Cyclooxygenase-Independent Pathway. Circulation 2000, 102, 2190-2196. [CrossRef] [PubMed]

76. Balaguer, J.M.; Yu, C.; Byrne, J.G.; Ball, S.K.; Petracek, M.R.; Brown, N.J.; Pretorius, M. Contribution of Endogenous Bradykinin to Fibrinolysis, Inflammation, and Blood Product Transfusion Following Cardiac Surgery: A Randomized Clinical Trial. Clin. Pharmacol. Ther. 2013, 93, 326-334. [CrossRef] [PubMed]

77. Jia, Z.; Tian, G.; Ren, Y.; Sun, Z.; Lu, W.; Hou, X. Pharmacokinetic Model of Unfractionated Heparin during and after Cardiopulmonary Bypass in Cardiac Surgery. J. Transl. Med. 2015, 13, 45. [CrossRef]

78. Boer, C.; Meesters, M.I.; Veerhoek, D.; Vonk, A.B.A. Anticoagulant and Side-Effects of Protamine in Cardiac Surgery: A Narrative Review. Br. J. Anaesth. 2018, 120, 914-927. [CrossRef]

79. Kindo, M.; Hoang Minh, T.; Gerelli, S.; Perrier, S.; Meyer, N.; Schaeffer, M.; Bentz, J.; Announe, T.; Mommerot, A.; Collange, O.; et al. Plasma Fibrinogen Level on Admission to the Intensive Care Unit Is a Powerful Predictor of Postoperative Bleeding after Cardiac Surgery with Cardiopulmonary Bypass. Thromb. Res. 2014, 134, 360-368. [CrossRef]

80. Vuylsteke, A.; Pagel, C.; Gerrard, C.; Reddy, B.; Nashef, S.; Aldam, P.; Utley, M. The Papworth Bleeding Risk Score: A Stratification Scheme for Identifying Cardiac Surgery Patients at Risk of Excessive Early Postoperative Bleeding. Eur. J. Cardio-Thorac. Surg. 2011, 39, 924-930. [CrossRef]

81. Emeklibas, N.; Kammerer, I.; Bach, J.; Sack, F.-U.; Hellstern, P. Preoperative Hemostasis and Its Association with Bleeding and Blood Component Transfusion Requirements in Cardiopulmonary Bypass Surgery: Preoperative Hemostasis and Bleeding. Transfusion 2013, 53, 1226-1234. [CrossRef] [PubMed] 
82. Bilecen, S.; de Groot, J.A.H.; Kalkman, C.J.; Spanjersberg, A.J.; Brandon Bravo Bruinsma, G.J.; Moons, K.G.M.; Nierich, A.P. Effect of Fibrinogen Concentrate on Intraoperative Blood Loss Among Patients With Intraoperative Bleeding During High-Risk Cardiac Surgery: A Randomized Clinical Trial. JAMA 2017, 317, 738. [CrossRef] [PubMed]

83. Ortmann, E.; Rubino, A.; Altemimi, B.; Collier, T.; Besser, M.W.; Klein, A.A. Validation of Viscoelastic Coagulation Tests during Cardiopulmonary Bypass. J. Thromb. Haemost. 2015, 13, 1207-1216. [CrossRef]

84. Fabbro, M.; Gutsche, J.T.; Miano, T.A.; Augoustides, J.G.; Patel, P.A. Comparison of Thrombelastography-Derived Fibrinogen Values at Rewarming and Following Cardiopulmonary Bypass in Cardiac Surgery Patients. Anesth. Analg. 2016, 123, 570-577. [CrossRef]

85. Erdoes, G.; Gerster, G.; Colucci, G.; Kaiser, H.; Alberio, L.; Eberle, B. Prediction of Post-Weaning Fibrinogen Status during Cardiopulmonary Bypass: An Observational Study in 110 Patients. PLoS ONE 2015, 10, e0126692. [CrossRef]

86. Mace, H.; Lightfoot, N.; McCluskey, S.; Selby, R.; Roy, D.; Timoumi, T.; Karkouti, K. Validity of Thromboelastometry for Rapid Assessment of Fibrinogen Levels in Heparinized Samples During Cardiac Surgery: A Retrospective, Single-Center, Observational Study. J. Cardiothorac. Vasc. Anesth. 2016, 30, 90-95. [CrossRef] [PubMed]

87. Solomon, C.; Baryshnikova, E.; Schlimp, C.J.; Schöchl, H.; Asmis, L.M.; Ranucci, M. FIBTEM PLUS Provides an Improved Thromboelastometry Test for Measurement of Fibrin-Based Clot Quality in Cardiac Surgery Patients. Anesth. Analg. 2013, 117, 1054-1062. [CrossRef] [PubMed]

88. Schlimp, C.J.; Solomon, C.; Ranucci, M.; Hochleitner, G.; Redl, H.; Schöchl, H. The Effectiveness of Different Functional Fibrinogen Polymerization Assays in Eliminating Platelet Contribution to Clot Strength in Thromboelastometry. Anesth. Analg. 2014, 118, 269-276. [CrossRef] [PubMed]

89. Sharma, S.; Kumar, S.; Tewari, P.; Pande, S.; Murari, M. Utility of Thromboelastography versus Routine Coagulation Tests for Assessment of Hypocoagulable State in Patients Undergoing Cardiac Bypass Surgery. Ann. Cardiac. Anaesth. 2018, $21,151$. [CrossRef]

90. Ranucci, M.; Baryshnikova, E. Fibrinogen Supplementation after Cardiac Surgery: Insights from the Zero-Plasma Trial (ZEPLAST). Br. J. Anaesth. 2016, 116, 618-623. [CrossRef] [PubMed]

91. Shams Hakimi, C.; Singh, S.; Hesse, C.; Jeppsson, A. Effects of Fibrinogen and Platelet Transfusion on Coagulation and Platelet Function in Bleeding Cardiac Surgery Patients. Acta Anaesthesiol. Scand. 2019, 63, 475-482. [CrossRef] [PubMed]

92. Ogawa, S.; Szlam, F.; Chen, E.P.; Nishimura, T.; Kim, H.; Roback, J.D.; Levy, J.H.; Tanaka, K.A. A Comparative Evaluation of Rotation Thromboelastometry and Standard Coagulation Tests in Hemodilution-Induced Coagulation Changes after Cardiac Surgery: THROMBOELASTOMETRY IN CPB SURGERY. Transfusion 2012, 52, 14-22. [CrossRef]

93. Solomon, C.; Cadamuro, J.; Ziegler, B.; Schöchl, H.; Varvenne, M.; Sørensen, B.; Hochleitner, G.; Rahe-Meyer, N. A Comparison of Fibrinogen Measurement Methods with Fibrin Clot Elasticity Assessed by Thromboelastometry, before and after Administration of Fibrinogen Concentrate in Cardiac Surgery Patients: Comparing Fibrinogen Measurement Methods. Transfusion 2011, 51, 1695-1706. [CrossRef] [PubMed]

94. Olde Engberink, R.H.G.; Kuiper, G.J.A.J.M.; Wetzels, R.J.H.; Nelemans, P.J.; Lance, M.D.; Beckers, E.A.M.; Henskens, Y.M.C. Rapid and Correct Prediction of Thrombocytopenia and Hypofibrinogenemia With Rotational Thromboelastometry in Cardiac Surgery. J. Cardiothorac. Vasc. Anesth. 2014, 28, 210-216. [CrossRef] [PubMed]

95. Ogawa, S.; Szlam, F.; Bolliger, D.; Nishimura, T.; Chen, E.P.; Tanaka, K.A. The Impact of Hematocrit on Fibrin Clot Formation Assessed by Rotational Thromboelastometry. Anesth. Analg. 2012, 115, 16-21. [CrossRef]

96. Hans, G.A.; Hartstein, G.; Roediger, L.; Hubert, B.; Peters, P.; Senard, M. Impact of 6 \% Hydroxyethyl Starch (HES) $130 / 0.4$ on the Correlation between Standard Laboratory Tests and Thromboelastography (TEG®) after Cardiopulmonary Bypass. Thromb. Res. 2015, 135, 984-989. [CrossRef] [PubMed]

97. Solomon, C.; Rahe-Meyer, N.; Schöchl, H.; Ranucci, M.; Görlinger, K. Effect of Haematocrit on Fibrin-Based Clot Firmness in the FIBTEM Test. Blood Transfus. 2013, 11, 412-418. [CrossRef] [PubMed]

98. Reynolds, P.S.; Middleton, P.; McCarthy, H.; Spiess, B.D. A Comparison of a New Ultrasound-Based Whole Blood Viscoelastic Test (SEER Sonorheometry) Versus Thromboelastography in Cardiac Surgery. Anesth. Analg. 2016, 123, 1400-1407. [CrossRef]

99. Espinosa, A.; Stenseth, R.; Videm, V.; Pleym, H. Comparison of Three Point-of-Care Testing Devices to Detect Hemostatic Changes in Adult Elective Cardiac Surgery: A Prospective Observational Study. BMC Anesthesiol. 2014, 14, 80. [CrossRef] [PubMed]

100. Groves, D.S.; Welsby, I.J.; Naik, B.I.; Tanaka, K.; Hauck, J.N.; Greenberg, C.S.; Winegar, D.A.; Viola, F. Multicenter Evaluation of the Quantra QPlus System in Adult Patients Undergoing Major Surgical Procedures. Anesth. Analg. 2020, 130, 899-909. [CrossRef] [PubMed]

101. Erdoes, G.; Schloer, H.; Eberle, B.; Nagler, M. Next Generation Viscoelasticity Assays in Cardiothoracic Surgery: Feasibility of the TEG6s System. PLoS ONE 2018, 13, e0209360. [CrossRef]

102. Vasques, F.; Spiezia, L.; Manfrini, A.; Tarzia, V.; Fichera, D.; Simioni, P.; Gerosa, G.; Ori, C.; Di Gregorio, G. Thromboelastometry Guided Fibrinogen Replacement Therapy in Cardiac Surgery: A Retrospective Observational Study. J. Anesth. 2017, 31, 286-290. [CrossRef]

103. Weber, C.F.; Görlinger, K.; Meininger, D.; Hermann, E.; Bingold, T.; Moritz, A.; Cohn, L.W.; Zacharowski, K. Point of Care Testing: A Prospective, Randomized Clinical Trial of Efficacy in Coagulopathic Cardiac Surgery Patients. Surv. Anesthesiol. 2013, 57, 167. [CrossRef] 
104. Kuiper, G.J.A.J.M.; van Egmond, L.T.; Henskens, Y.M.C.; Roekaerts, P.M.; Maessen, J.G.; ten Cate, H.; Buhre, W.F.; Lancé, M.D. Shifts of Transfusion Demand in Cardiac Surgery After Implementation of Rotational Thromboelastometry-Guided Transfusion Protocols: Analysis of the HEROES-CS (HEmostasis Registry of PatiEntS in Cardiac Surgery) Observational, Prospective Open Cohort Database. J. Cardiothorac. Vasc. Anesth. 2019, 33, 307-317. [CrossRef]

105. Sarrais Polo, C.; Alonso Morenza, A.; Rey Picazo, J.; Álvarez Mercadal, L.; Beltrao Sial, R.; Aguilar Lloret, C. Thromboelastometry as Guidance for Blood Management in Patients Undergoing Cardiac Surgery. Rev. Española Anestesiol. Reanim. 2018, 65, 129-134. [CrossRef]

106. Waldén, K.; Jeppsson, A.; Nasic, S.; Backlund, E.; Karlsson, M. Low Preoperative Fibrinogen Plasma Concentration Is Associated With Excessive Bleeding After Cardiac Operations. Ann. Thorac. Surg. 2014, 97, 1199-1206. [CrossRef] [PubMed]

107. Rafiq, S.; Johansson, P.I.; Kofoed, K.F.; Olsen, P.S.; Steinbrüchel, D.A. Preoperative Hemostatic Testing and the Risk of Postoperative Bleeding in Coronary Artery Bypass Surgery Patients. J. Card. Surg. 2016, 31, 565-571. [CrossRef] [PubMed]

108. Gielen, C.; Dekkers, O.; Stijnen, T.; Schoones, J.; Brand, A.; Klautz, R.; Eikenboom, J. The Effects of Pre- and Postoperative Fibrinogen Levels on Blood Loss after Cardiac Surgery: A Systematic Review and Meta-Analysis. Interact. Cardiovasc. Thorac. Surg. 2014, 18, 292-298. [CrossRef]

109. Charbonneau, H.; Pasquie, M.; Mayeur, N. Preoperative Plasma Fibrinogen Level and Transfusion in Cardiac Surgery: A Biphasic Correlation. Interact. Cardiovasc. Thorac. Surg. 2020, 31, 622-625. [CrossRef] [PubMed]

110. Mazur, P.; Natorska, J.; Sobczyk, D.; Gawęda, B.; Bartuś, K.; Filip, G.; Kapelak, B.; Undas, A. Plasma Fibrin Clot Properties Affect Blood Loss after Surgical Aortic Valve Replacement for Aortic Stenosis. Eur. J. Cardio-Thorac. Surg. 2019, 55, 224-231. [CrossRef] [PubMed]

111. Yang, J.J.; Lei, W.H.; Hu, P.; Wu, B.B.; Chen, J.X.; Ni, Y.M.; Lai, E.Y.; Han, F.; Chen, J.H.; Yang, Y. Preoperative Serum Fibrinogen Is Associated With Acute Kidney Injury after Cardiac Valve Replacement Surgery. Sci. Rep. 2020, 10, 6403. [CrossRef] [PubMed]

112. Yang, L.; Vuylsteke, A.; Gerrard, C.; Besser, M.; Baglin, T. Postoperative Fibrinogen Level Is Associated with Postoperative Bleeding Following Cardiothoracic Surgery and the Effect of Fibrinogen Replacement Therapy Remains Uncertain. J. Thromb. Haemost. 2013, 11, 1519-1526. [CrossRef] [PubMed]

113. Kawashima, S.; Suzuki, Y.; Sato, T.; Kikura, M.; Katoh, T.; Sato, S. Four-Group Classification Based on Fibrinogen Level and Fibrin Polymerization Associated With Postoperative Bleeding in Cardiac Surgery. Clin. Appl. Thromb. Hemost. 2016, 22, 648-655. [CrossRef]

114. Karkouti, K.; Callum, J.; Crowther, M.A.; McCluskey, S.A.; Pendergrast, J.; Tait, G.; Yau, T.M.; Beattie, W.S. The Relationship Between Fibrinogen Levels After Cardiopulmonary Bypass and Large Volume Red Cell Transfusion in Cardiac Surgery: An Observational Study. Anesth. Analg. 2013, 117, 14-22. [CrossRef]

115. Ranucci, M.; Pistuddi, V.; Baryshnikova, E.; Colella, D.; Bianchi, P. Fibrinogen Levels After Cardiac Surgical Procedures: Association With Postoperative Bleeding, Trigger Values, and Target Values. Ann. Thorac. Surg. 2016, 102, 78-85. [CrossRef]

116. Ranucci, M.; Jeppsson, A.; Baryshnikova, E. Pre-Operative Fibrinogen Supplementation in Cardiac Surgery Patients: An Evaluation of Different Trigger Values: Pre-Operative Fibrinogen Supplementation. Acta Anaesthesiol. Scand. 2015, 59, 427-433. [CrossRef] [PubMed]

117. Kim, N.Y.; Shim, J.-K.; Song, J.W.; Kim, E.-K.; Kwak, Y.-L. Impact of Preoperative Fibrinogen Concentration on Postoperative Outcome in Patients Who Received Dual Antiplatelet Therapy in Proximity to Off-Pump Coronary Bypass Surgery. Circ. J. 2014, 78, 1661-1666. [CrossRef] [PubMed]

118. Ranucci, M.; Baryshnikova, E.; Crapelli, G.B.; Rahe-Meyer, N.; Menicanti, L.; Frigiola, A.; the Surgical Clinical Outcome REsearch (SCORE) Group. Randomized, Double-Blinded, Placebo-Controlled Trial of Fibrinogen Concentrate Supplementation After Complex Cardiac Surgery. JAHA 2015, 4. [CrossRef] [PubMed]

119. Liu, X.; Zhang, W.; Chen, N.; Wang, L.; Wang, S.; Yu, Y.; Ao, H. Can Preoperative C-Reactive Protein Predict Bleeding After On-Pump Coronary Artery Bypass Grafting? Ann. Thorac. Surg. 2020, 109, 541-546. [CrossRef]

120. Theusinger, O.M.; Baulig, W.; Seifert, B.; Emmert, M.Y.; Spahn, D.R.; Asmis, L.M. Relative Concentrations of Haemostatic Factors and Cytokines in Solvent/Detergent-Treated and Fresh-Frozen Plasma. Br. J. Anaesth. 2011, 106, 505-511. [CrossRef] [PubMed]

121. Levy, J.H.; Szlam, F.; Tanaka, K.A.; Sniecienski, R.M. Fibrinogen and Hemostasis: A Primary Hemostatic Target for the Management of Acquired Bleeding. Anesth. Analg. 2012, 114, 261-274. [CrossRef] [PubMed]

122. Yang, L.; Stanworth, S.; Baglin, T. Cryoprecipitate: An Outmoded Treatment?: Cryoprecipitate: An Outmoded Treatment? Transfus. Med. 2012, 22, 315-320. [CrossRef] [PubMed]

123. Lee, S.H.; Lee, S.M.; Kim, C.S.; Cho, H.S.; Lee, J.-H.; Lee, C.H.; Kim, E.; Sung, K.; Solomon, C.; Kang, J.; et al. Fibrinogen Recovery and Changes in Fibrin-Based Clot Firmness after Cryoprecipitate Administration in Patients Undergoing Aortic Surgery Involving Deep Hypothermic Circulatory Arrest: Fibrinogen Recovery with Cryoprecipitate. Transfusion 2014, 54, $1379-1387$. [CrossRef]

124. Callum, J.; Farkouh, M.E.; Scales, D.C.; Heddle, N.M.; Crowther, M.; Rao, V.; Hucke, H.-P.; Carroll, J.; Grewal, D.; Brar, S.; et al. Effect of Fibrinogen Concentrate vs Cryoprecipitate on Blood Component Transfusion After Cardiac Surgery: The FIBRES Randomized Clinical Trial. JAMA 2019, 322, 1966. [CrossRef]

125. Waldén, K.; Jeppsson, A.; Nasic, S.; Karlsson, M. Fibrinogen Concentrate to Cardiac Surgery Patients with Ongoing Bleeding Does Not Increase the Risk of Thromboembolic Complications or Death. Thromb. Haemost. 2020, 120, 384-391. [CrossRef] [PubMed] 
126. Fassl, J.; Lurati Buse, G.; Filipovic, M.; Reuthebuch, O.; Hampl, K.; Seeberger, M.D.; Bolliger, D. Perioperative Administration of Fibrinogen Does Not Increase Adverse Cardiac and Thromboembolic Events after Cardiac Surgery. Br. J. Anaesth. 2015, 114, 225-234. [CrossRef] [PubMed]

127. Colin-Bracamontes, I.; Pérez-Calatayud, Á.A.; Carrillo-Esper, R.; Rodríguez-Ayala, E.; Padilla-Molina, M.; Posadas-Nava, A.; Olvera-Vázquez, S.; Hernández-Salgado, L. Observational Safety Study of Clottafact ${ }^{\circledR F i b r i n o g e n ~ C o n c e n t r a t e: ~ R e a l-W o r l d ~ D a t a ~}$ in Mexico. Clin. Drug Investig. 2020, 40, 485-491. [CrossRef] [PubMed]

128. Maeda, T.; Miyata, S.; Usui, A.; Nishiwaki, K.; Tanaka, H.; Okita, Y.; Katori, N.; Shimizu, H.; Sasaki, H.; Ohnishi, Y.; et al. Safety of Fibrinogen Concentrate and Cryoprecipitate in Cardiovascular Surgery: Multicenter Database Study. J. Cardiothorac. Vasc. Anesth. 2019, 33, 321-327. [CrossRef] [PubMed]

129. Jeppsson, A.; Waldén, K.; Roman-Emanuel, C.; Thimour-Bergström, L.; Karlsson, M. Preoperative Supplementation with Fibrinogen Concentrate in Cardiac Surgery: A Randomized Controlled Study. Br. J. Anaesth. 2016, 116, 208-214. [CrossRef] [PubMed]

130. Sadeghi, M.; Atefyekta, R.; Azimaraghi, O.; Marashi, S.M.; Aghajani, Y.; Ghadimi, F.; Spahn, D.R.; Movafegh, A. A Randomized, Double Blind Trial of Prophylactic Fibrinogen to Reduce Bleeding in Cardiac Surgery. Braz. J. Anesthesiol. 2014, 64, $253-257$. [CrossRef]

131. Rahe-Meyer, N.; Levy, J.H.; Mazer, C.D.; Schramko, A.; Klein, A.A.; Brat, R.; Okita, Y.; Ueda, Y.; Schmidt, D.S.; Ranganath, R.; et al. Randomized Evaluation of Fibrinogen vs Placebo in Complex Cardiovascular Surgery (REPLACE): A Double-Blind Phase III Study of Haemostatic Therapy. Br. J. Anaesth. 2016, 117, 41-51. [CrossRef]

132. Bilecen, S.; Peelen, L.M.; Kalkman, C.J.; Spanjersberg, A.J.; Moons, K.G.M.; Nierich, A.P. Fibrinogen Concentrate Therapy in Complex Cardiac Surgery. J. Cardiothorac. Vasc. Anesth. 2013, 27, 12-17. [CrossRef]

133. Karlsson, M.; Ternström, L.; Hyllner, M.; Baghaei, F.; Skrtic, S.; Jeppsson, A. Prophylactic Fibrinogen Infusion in Cardiac Surgery Patients: Effects on Biomarkers of Coagulation, Fibrinolysis, and Platelet Function. Clin. Appl. Thromb. Hemost. 2011, 17, 396-404. [CrossRef] [PubMed]

134. Rahe-Meyer, N.; Solomon, C.; Hanke, A.; Schmidt, D.S.; Knoerzer, D.; Hochleitner, G.; Sørensen, B.; Hagl, C.; Pichlmaier, M. Effects of Fibrinogen Concentrate as First-Line Therapy during Major Aortic Replacement Surgery: A Randomized, Placebo-Controlled Trial. Anesthesiology 2013, 118, 40-50. [CrossRef] [PubMed]

135. Lupu, I.-M.; Rebaine, Z.; Lhotel, L.; Watremez, C.; Eeckhoudt, S.; Van Dyck, M.; Momeni, M. A Low-Dose Human Fibrinogen Is Not Effective in Decreasing Postoperative Bleeding and Transfusion Requirements during Cardiac Surgery in Case of Concomitant Clinical Bleeding and Low FIBTEM Values: A Retrospective Matched Study. Ann. Card. Anaesth. 2018, 21, 262. [CrossRef] [PubMed]

136. Kozek-Langenecker, S.A.; Afshari, A.; Albaladejo, P.; Santullano, C.A.A.; De Robertis, E.; Filipescu, D.C.; Fries, D.; Görlinger, K.; Haas, T.; Imberger, G.; et al. Management of Severe Perioperative Bleeding: Guidelines from the European Society of Anaesthesiology. Eur. J. Anaesthesiol. EJA 2013, 30, 270-382. [CrossRef] [PubMed]

137. Wikkelsø, A.; Lunde, J.; Johansen, M.; Stensballe, J.; Wetterslev, J.; Møller, A.M.; Afshari, A. Fibrinogen Concentrate in Bleeding Patients. Cochrane Database Syst. Rev. 2013. [CrossRef]

138. Rahe-Meyer, N.; Levy, J.H.; Mazer, C.D.; Schramko, A.; Klein, A.A.; Brat, R.; Okita, Y.; Ueda, Y.; Schmidt, D.S.; Gill, R. Randomized Evaluation of Fibrinogen versus Placebo in Complex Cardiovascular Surgery: Post Hoc Analysis and Interpretation of Phase III Results. Interact. Cardiovasc. Thorac. Surg. 2019, 28, 566-574. [CrossRef]

139. Li, J.-Y.; Gong, J.; Zhu, F.; Moodie, J.; Newitt, A.; Uruthiramoorthy, L.; Cheng, D.; Martin, J. Fibrinogen Concentrate in Cardiovascular Surgery: A Meta-Analysis of Randomized Controlled Trials. Anesth. Analg. 2018, 127, 612-621. [CrossRef]

140. Ranucci, M.; Baryshnikova, E.; Ranucci, M.; Silvetti, S. Fibrinogen Levels Compensation of Thrombocytopenia-Induced Bleeding Following Cardiac Surgery. Int. J. Cardiol. 2017, 249, 96-100. [CrossRef] [PubMed]

141. Haensig, M.; Kempfert, J.; Kempfert, P.-M.; Girdauskas, E.; Borger, M.A.; Lehmann, S. Thrombelastometry Guided BloodComponent Therapy after Cardiac Surgery: A Randomized Study. BMC Anesthesiol. 2019, 19, 201. [CrossRef]

142. Scolletta, S.; Simioni, P.; Campagnolo, V.; Celiento, M.; Fontanari, P.; Guadagnucci, A.; Guarracino, F.; Haxhiademi, D.; Paniccia, R.; Simeone, F.; et al. Patient Blood Management in Cardiac Surgery: The “Granducato Algorithm”. Int. J. Cardiol. 2019, 289 , 37-42. [CrossRef] [PubMed]

143. Pajares, A.; Larrea, L.; Zarragoikoetexea, I.; Tur, A.; Vicente, R.; Argente, P. Patient Blood Management in Cardiac Surgery: Results. Rev. Española Anestesiol. Reanim. 2018, 65, 196-203. [CrossRef] [PubMed]

144. Ranucci, M.; Baryshnikova, E.; Pistuddi, V.; Menicanti, L.; Frigiola, A. The Effectiveness of 10 Years of Interventions to Control Postoperative Bleeding in Adult Cardiac Surgery. Interact. Cardiovasc. Thorac. Surg. 2016, 24, 196-202. [CrossRef] [PubMed]

145. Birla, R.; Nawaytou, O.; Shaw, M.; Jackson, A.; Mills, K.; Kuduvalli, M.; Field, M.; Agarwal, S. Reducing Blood Transfusion in Aortic Surgery: A Novel Approach. Ann. Thorac. Surg. 2019, 108, 1369-1375. [CrossRef] [PubMed]

146. Trevisan, D.; Zavatti, L.; Gabbieri, D.; Pedulli, M.; Giordano, G.; Meli, M. Point-of-Care-Based Protocol with First-Line Therapy with Coagulation Factor Concentrates Is Associated with Decrease Allogenic Blood Transfusion and Costs in Cardiovascular Surgery: An Italian Single-Center Experience. Minerva Anestesiol. 2016, 82, 12. 